Historic, Archive Document

Do not assume content reflects current scientific knowledge, policies, or practices. 

25011
.93

United States Agriculture

Forest Service

Pacific Southwest

Forest and Range

Experiment Station

Resource Bulletin

PSW-22

\section{Vegetation Survey of the Republic of Palau}

\author{
Thomas G. Cole
}

Craig D. Whitesell
Marjorie C. Falanruw

Colin D. MacLean

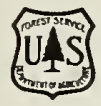

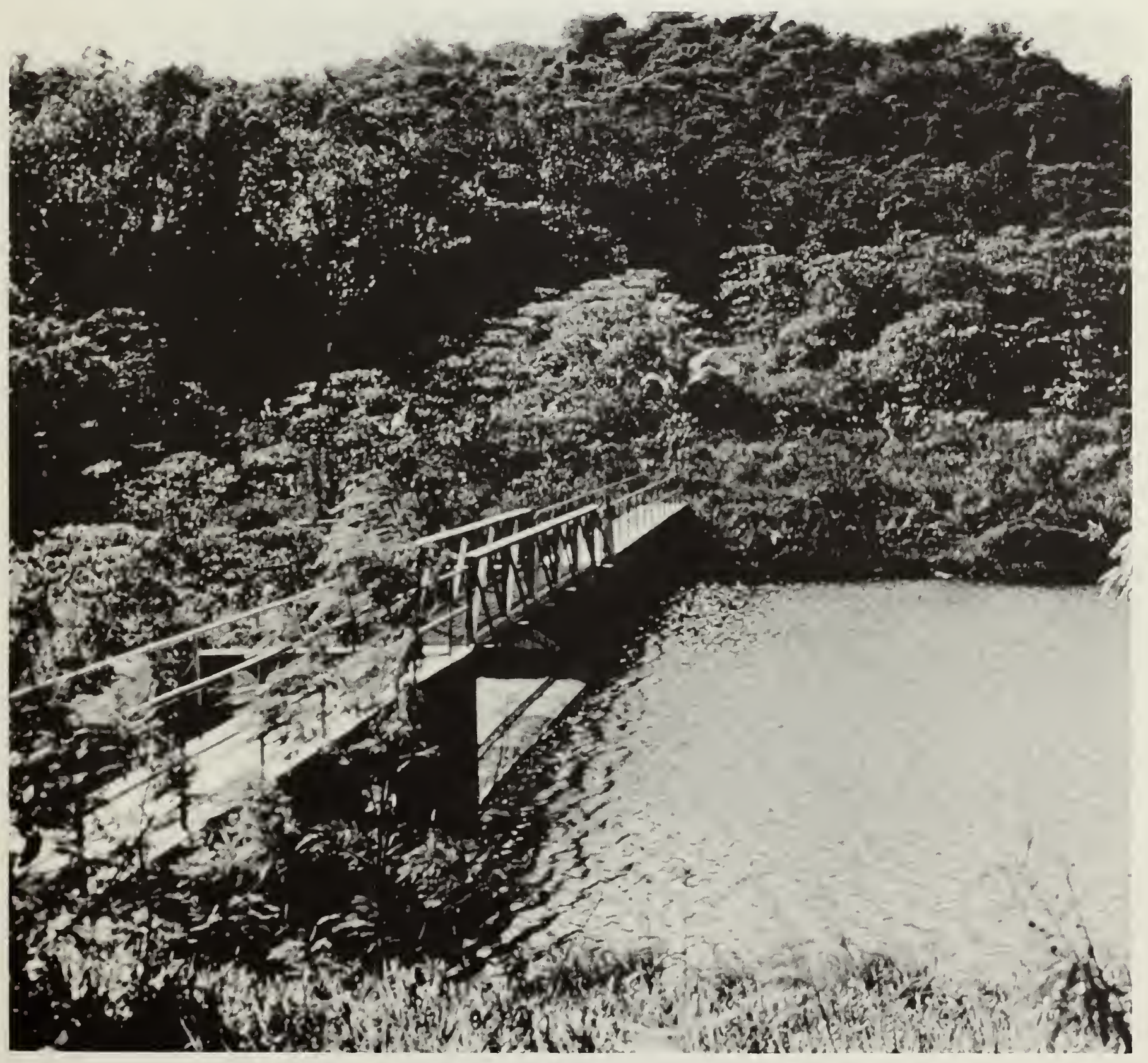




\section{The Authors:}

THOMAS G. COLE, a forester with the American Pacific Islands Forestry Research Work Unit in Honolulu, was stationed in Koror, Palau, at the time of the vegetation survey reported here. He received a bachelor's in forest sciences (1977) from Texas A\&M University. MARJORIE C. FALANRUW, a research biologist with the same unit, is stationed in Yap. She holds degrees in biology from the University of California (bachelor's 1965) and the University of Guam (master's 1969). COLIN D. MACLEAN is principal mensurationist with the Forest Inventory and Analysis Research Work Unit, Pacific Northwest Forest and Range Experiment Station, in Portland, Oregon. He earned a bachelor's in forestry (1950) from the University of Maine, and a master's in forest management (1951) from the College of Environmental Science and Forestry, State University of New York. CRAIG D. WHITESELL, principal silviculturist, is leader of the Station's American Pacific Islands Forestry research in Honolulu. He has a bachelor's in forest management (1951) from West Virginia University and a master's in silviculture (1954) from Duke University. ALAN H. AMBACHER is supervisory cartographer in the Forest Service's Pacific Southwest regional office in San Francisco. He attended the Milwaukee School of Engineering.

\section{Acknowledgments:}

We thank the staffs of the U.S. Trust Territory of the Pacific Islands and the Soil Conservation Service, U.S. Department of Agriculture, for their assistance in this survey. Trust Territory participants included David Idip, chief of agriculture; Robert Ray, staff forester; and Kozo Yamada, director of natural resources. Soil Conservation Service participants included Jack Kanalz, former State conservationist, and Harry Sato, Hawaii State soil scientist.

We also thank the following individuals from Palau who assisted in the survey: Neil Morriss, former district agriculturist; Herman Francisco, assistant agriculturist; James Remarii, district forester; Marcello Brel, forester; Gerdence Meyer, forester; Ebais Sadang, forester, and Thomas Watson, former Peace Corps forester.

Cover: Upland forest surrounding a water reservoir which supplies water to the city of Koror, Island of Babelthuap, Republic of Palau.

Publisher

Pacific Southwest Forest and Range Experiment Station P.O. Box 245, Berkeley, California 94701

In cooperation with:

Pacific Northwest Forest and Range Experiment Station

P.O. Box 3890, Portland, Oregon 97208

\section{Forest Service}

U.S. Department of Agriculture

June 1987 


\title{
Vegetation Survey of the Republic of Palau
}

\author{
Craig D. Whitesell \\ Colin D. MacLean \\ Marjorie C. Falanruw \\ Thomas G. Cole \\ Alan H. Ambacher
}

\section{CONTENTS}

Introduction $. \ldots \ldots \ldots \ldots \ldots \ldots \ldots \ldots \ldots \ldots \ldots \ldots \ldots \ldots \ldots \ldots \ldots, 1$

Geography and Climate..........................

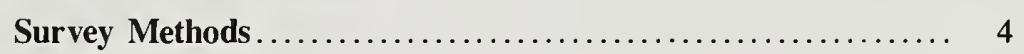

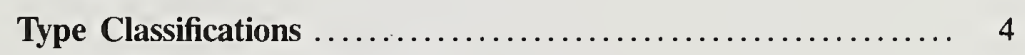

Vegetation Type Descriptions....................... 5

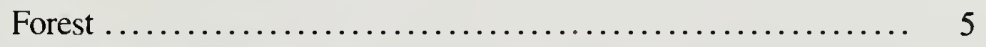

Secondary Vegetation $\ldots \ldots \ldots \ldots \ldots \ldots \ldots \ldots \ldots \ldots \ldots \ldots \ldots, 11$

Agroforest................................ 11

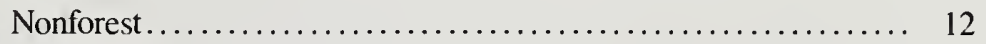

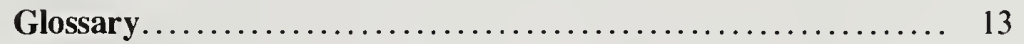

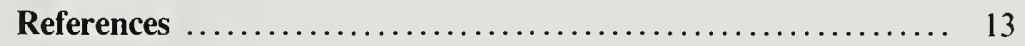





\section{INTRODUCTION}

$\mathrm{P}$ alau is an archipelago of high and low islands located in the western Caroline Islands. The largest island in the group is the heavily forested high island of Babelthuap. Knowledge of the soils and the extent and composition of Palau's vegetation, including the forests, is needed for land-use planning. To fill this need, a formal agreement was drawn up between the High Commissioner of the Trust Territory of the Pacific Islands, and two agencies of the U.S. Department of Agriculture-the Soil Conservation Service and the Forest Service.

Vegetation maps of Palau are a product of this agreement. They were prepared by the Forest Service in cooperation with the government of Palau, and are intended to serve as a working tool for natural resource managers and as a base for resource inventories.
This bulletin describes the different vegetation types, their ecological function and uses for 42 islands in Palau, and includes 17 map sections inside the back cover.

\section{GEOGRAPHY AND CLIMATE}

The Republic of Palau, lat. $7^{\circ} 20^{\prime} \mathrm{N}$ and long. $134^{\circ} 28^{\prime} \mathrm{E}$, is located at the extreme western edge of the Caroline Islands. The archipelago lies about $800 \mathrm{~km}$ (500 statute mi) north of the equator, $800 \mathrm{~km}$ east of the Philippine Islands, and $6,000 \mathrm{~km}(3,750$ statute mi) southwest of Hawaii (fig. 1). The island group consists of four volcanic high islands and approximately 200 low and raised coral and coralline limestone islands.

Most of the Republic's usable forest resource is in the centrally

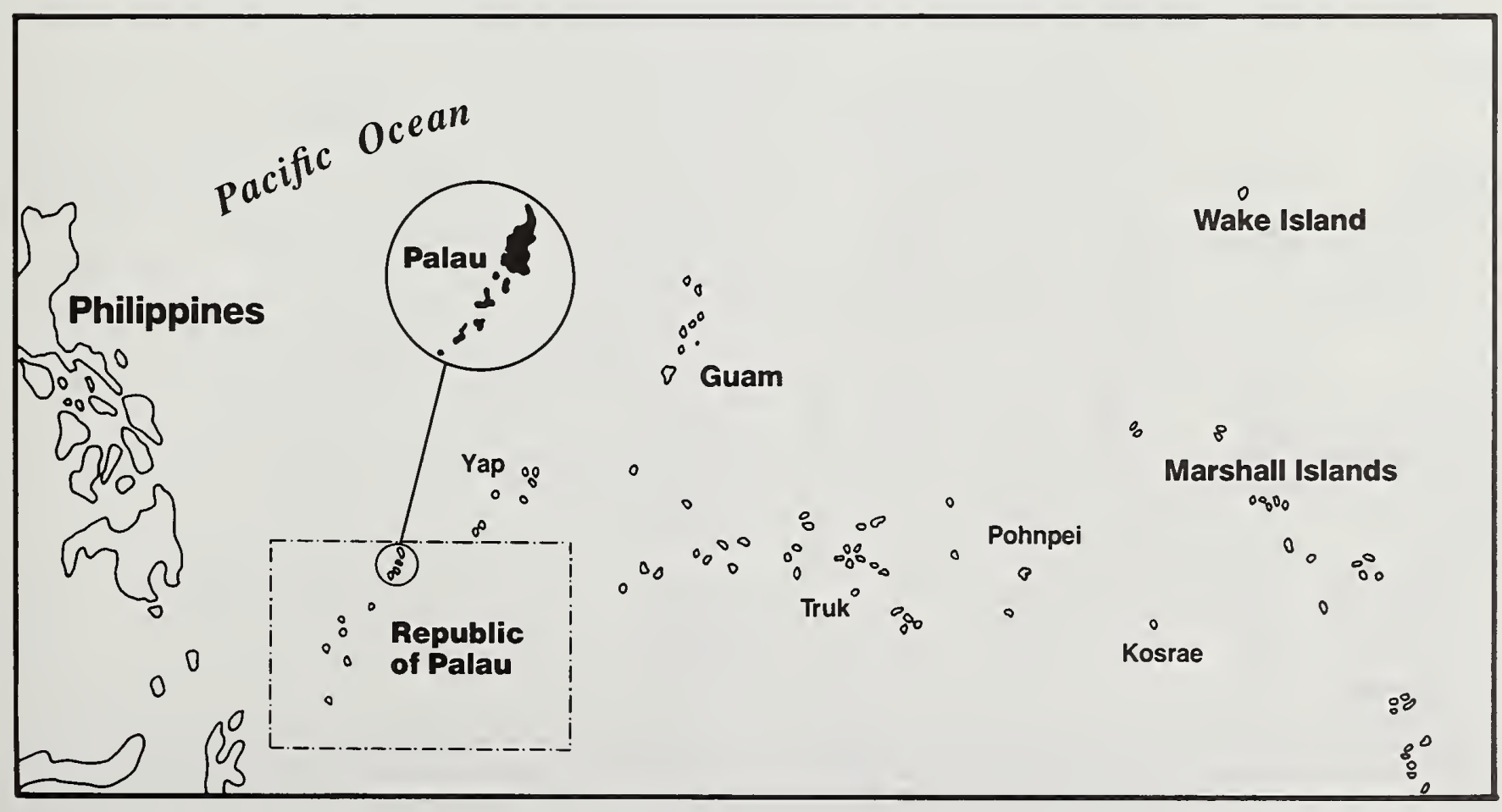

Figure 1-The Republic of Palau is located in the Western Caroline Islands. 
located high island of Babelthuap (tables I and 2, figs. 1, 2 and 3). Babelthuap and the other high islands of the Republic-Malakal, Ngerekebesang, and Koror-(table 3) are characterized by low. rolling hills, coastal bottomlands, and tidal flats. Maximum elevation is about $215 \mathrm{~m}(700 \mathrm{ft})$.

Thirty-eight smaller islands were also surveyed during the project. Peleliu and Angaur, the two major islands to the south, are raised coral islands with jagged hills and level coastal areas (table 4). Much of the native vegetation on these two islands was destroyed during World War II, although remnants of limestone forest can still be found in the hills. Secondary vegetation, commonly found after disturbance, grows on 50 percent of the land area of Peleliu and on 68 percent of Angaur.

The famed Rock Islands of Palau are extremely steep, coralline limestone islands, typically undercut along the water's edge. They occupy the area from Koror Island south to the island of Peleliu. We actually surveyed only one-fifth of the Rock Islands due to incomplete aerial photography. A summary of the vegetation found on 35 Rock Islands is found in table 5 and a detailed breakdown by island and state, in table $6 \mathrm{~A}-\mathrm{C}$.

Palau is hot and humid. The mean annual temperature of Koror, the capitol, is $27^{\circ} \mathrm{C}\left(81^{\circ} \mathrm{F}\right)$, with a mean annual rainfall of $3,730 \mathrm{~mm}$ (147 in). Rainfall varies little from month to monthFebruary, March, and April are slightly drier than average. Relative humidity of the area averages about 90 percent at night and from 75 to 80 percent during the day. The average diurnal range of temperatures is $7{ }^{\circ} \mathrm{C}\left(12^{\circ} \mathrm{F}\right)$. Although Palau lies outside the main paths of severe tropical disturbances and typhoons, such storms with high winds occasionally hit the islands, causing damage to crops, trees, and dwellings. In March 1967, the most destructive storm recorded struck with winds of $117 \mathrm{kph}$ (73 mph).

Table 1-Area of Republic of Palau by island group, land class and type, 1979

\begin{tabular}{|c|c|c|c|c|c|c|}
\hline \multirow[b]{2}{*}{$\begin{array}{l}\text { Land class } \\
\text { and type }\end{array}$} & \multirow[b]{2}{*}{ Symbol } & \multicolumn{4}{|c|}{ 1sland Group } & \multirow[b]{2}{*}{ Total } \\
\hline & & $\begin{array}{l}\text { Babel- } \\
\text { thuap }\end{array}$ & $\begin{array}{l}\text { Other } \\
\text { high } \\
\text { islands }\end{array}$ & $\begin{array}{c}\text { Coral } \\
\text { 1slands }\end{array}$ & $\begin{array}{l}\text { Rock } \\
\text { 1slands }\end{array}$ & \\
\hline & & & 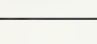 & Hectare. & (acres) & \\
\hline \multicolumn{7}{|l|}{ Forest } \\
\hline Upland forest & UP & 21,690 & 201 & 0 & 0 & $21,891 \quad(54,093)$ \\
\hline Swamp forest & SW & 1,617 & 15 & 47 & 1 & $1,680(4,151)$ \\
\hline Mangrove forest & $\mathrm{MN}$ & 4,025 & 205 & 435 & 43 & $4,708(11,633)$ \\
\hline Plantation forest & $\mathrm{PF}$ & 24 & 2 & 0 & 0 & $26(64)$ \\
\hline Rock lsland forest & RI & 104 & 210 & 0 & 802 & $1,116(2,758)$ \\
\hline Limestone forest & $\mathrm{L} 1$ & 0 & 0 & 1,175 & 57 & $1,232(3,044)$ \\
\hline Casuarina forest & $\mathrm{CA}$ & 0 & 0 & 451 & 0 & $451(1,114)$ \\
\hline Atoll forest & AT & 0 & 0 & 97 & 58 & $155(383)$ \\
\hline Palm forest & $\mathrm{PO}$ & 0 & $<1$ & 0 & 0 & $<1$ (1) \\
\hline Total forest & & 27,460 & 633 & 2,205 & 961 & $31,259(77,241)$ \\
\hline $\begin{array}{l}\text { Secondary } \\
\text { vegetation }\end{array}$ & SV & 515 & 79 & 131 & 2 & $727(1,796)$ \\
\hline \multicolumn{7}{|l|}{ Agroforest } \\
\hline $\begin{array}{l}\text { Agroforest } \\
\text { Agroforest }\end{array}$ & $\mathrm{AG}$ & 8 & 0 & 2 & 6 & $16(40)$ \\
\hline (w/coconut) & AG.CO & 173 & 6 & 100 & 0 & $279(689)$ \\
\hline Coconut plantation & $\mathrm{CO}$ & 743 & 0 & 0 & 71 & $814(2,011)$ \\
\hline Total agroforest & & 924 & 6 & 102 & 77 & $1,109(2,740)$ \\
\hline \multicolumn{7}{|l|}{ Nonforest } \\
\hline Marsh, fresh & M.F & 448 & $<1$ & 27 & 0 & $475(1,174)$ \\
\hline Marsh, cultivated & M.C & 107 & 2 & 25 & 0 & $134(331)$ \\
\hline Marsh, saline & M.S & 0 & 0 & 25 & $<1$ & $25(62)$ \\
\hline Grassland & G & 6,728 & 53 & 1 & 1 & $6,783(16,761)$ \\
\hline Strand & $S$ & 0 & 0 & 10 & 1 & $11(27)$ \\
\hline Cropland & $\mathrm{C}$ & 140 & 59 & 4 & 0 & $203(502)$ \\
\hline $\begin{array}{l}\text { Cropland/secondary } \\
\text { vegetation }\end{array}$ & $\mathrm{C} / \mathrm{SV}$ & 0 & 28 & 0 & 0 & $28(69)$ \\
\hline Urban & $\mathrm{U}$ & 141 & 222 & 33 & 1 & $397(981)$ \\
\hline Urban/cropland & $\mathrm{U} / \mathrm{C}$ & 106 & 70 & 0 & 0 & $176(435)$ \\
\hline Urban/agroforest & $\mathrm{U} / \mathrm{A}$ & 0 & 0 & 61 & 0 & $61(151)$ \\
\hline Urban/secondary & & & & & & \\
\hline vegetation & $\mathrm{U} / \mathrm{SV}$ & 0 & 3 & 0 & 0 & $3(70)$ \\
\hline Barren & B & 149 & 5 & 26 & 0 & 180 \\
\hline Water & W & 15 & 9 & 17 & 7 & $48(119)$ \\
\hline Total nonforest & & 7,834 & 451 & 229 & 10 & $8,524(21,063)$ \\
\hline Total area & & 36,733 & 1,169 & 2,667 & 1,050 & $41,619(102.840)$ \\
\hline
\end{tabular}


Table 2-Area of forest land, by size and density classes, Babelthuap Island, Republic of Palau, 1979

\begin{tabular}{|c|c|c|c|c|c|}
\hline \multirow[b]{2}{*}{ Type } & \multirow{2}{*}{$\begin{array}{l}\text { Size } \\
\text { class' }\end{array}$} & \multicolumn{3}{|c|}{ Density classes ${ }^{2}$} & \multirow{2}{*}{ Total } \\
\hline & & Low & Medium & High & \\
\hline \multirow[b]{2}{*}{ Upland Forest } & \multirow[b]{2}{*}{0} & \multicolumn{3}{|c|}{ - Hectares (acres } & \\
\hline & & 0 & 6 & 639 & $645(1,593)$ \\
\hline Upland Forest & 1 & 246 & 424 & 15,791 & $16,461 \quad(40,677)$ \\
\hline Upland Forest & 2 & 3 & 638 & 3,943 & $4,584 \quad(11,326)$ \\
\hline Swamp Forest & 0 & 0 & 2 & 2 & $4(9)$ \\
\hline Swamp Forest & 1 & 357 & 705 & 347 & $1,409(3,481)$ \\
\hline Swamp Forest & 2 & 88 & 65 & 51 & $204(505)$ \\
\hline Mangrove & 0 & 0 & 0 & 459 & $459(1,134)$ \\
\hline Mangrove & 1 & 5 & 0 & 3,395 & $3,400(8,401)$ \\
\hline Mangrove & 2 & 0 & 0 & 166 & $166(411)$ \\
\hline Rock Island Forest & 1 & 0 & 0 & 103 & $103(255)$ \\
\hline Rock Island Forest & 2 & 0 & 0 & 1 & $1(2)$ \\
\hline Plantation Forest & 1 & 0 & 0 & 24 & $24(60)$ \\
\hline Total forest land & & 699 & 1,840 & 24,921 & $27,460(67,854)$ \\
\hline
\end{tabular}

'0-Short, shrub-like trees smaller than $12.5 \mathrm{~cm}$ in d.b.h.

1-Trees averaging less than $30 \mathrm{~cm}$ in d.b.h., but larger than $12.5 \mathrm{~cm}$ in d.b.h.

2-Trees averaging $30 \mathrm{~cm}$ or more in d.b.h.

${ }^{2}$ Crown closure of main canopy: low $<30$ pct; medium 30-70 pct; high $>70$ pct.

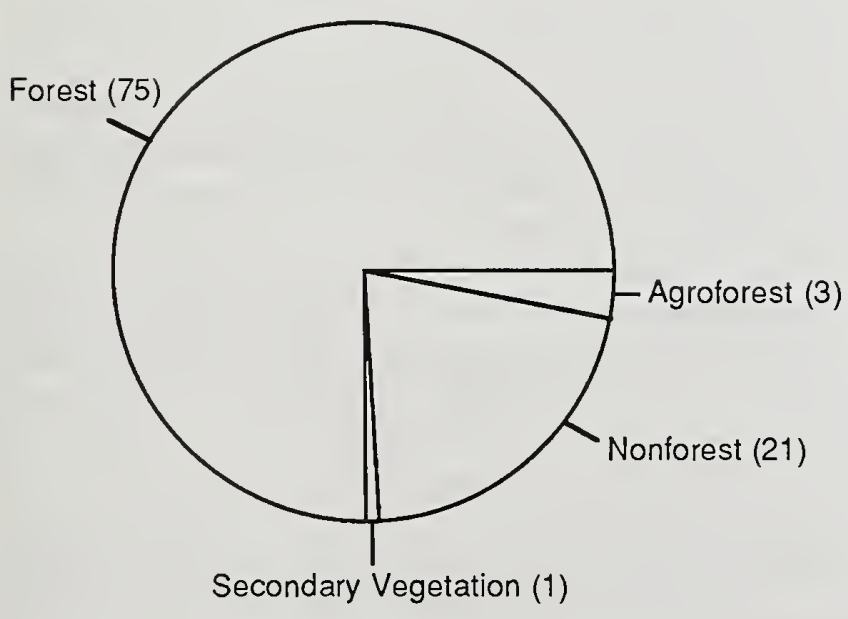

Figure 3-Areal percentages of land classes, Republic of Palau in 1979 show that the forest class is by far the largest. Eighty-six percent of the nonforest class or 18 percent of the total land area of Babelthuap Island is grassland.

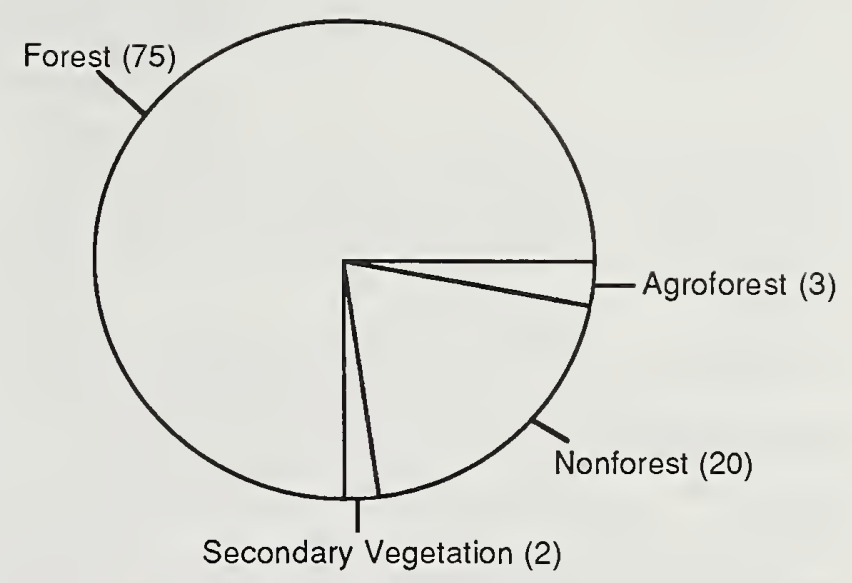

Figure 2-Areal percentages of land classes, Republic of Palau, in 1979.

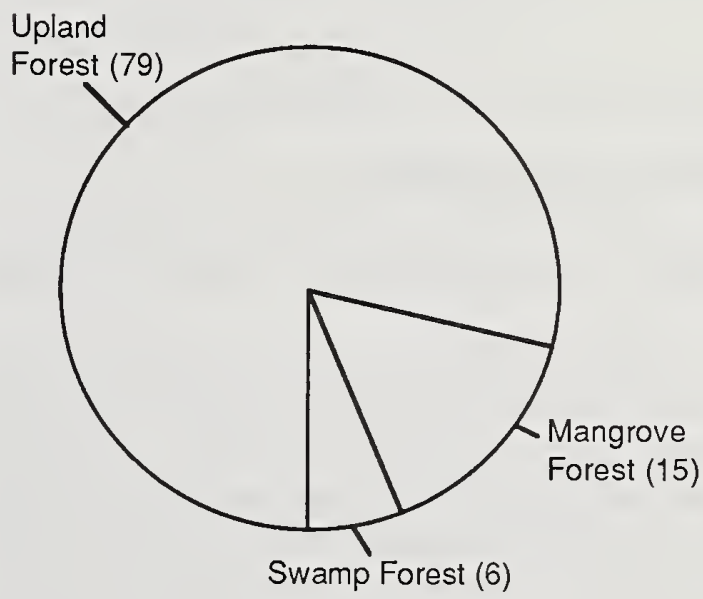

Figure 4-Percentages of land area in the major forest types, Babelthuap Island, Republic of Palau, 1979. The plantation and Rock Island forest types comprise less than 1 percent of the total area. 
Table 3-Area of the high islands of Koror, Malakal, and Ngerekebesang, Republic of Palau, by island, land class, and type, 1979

\begin{tabular}{|c|c|c|c|c|c|}
\hline \multirow{2}{*}{$\begin{array}{l}\text { Land class } \\
\text { and type }\end{array}$} & \multirow{2}{*}{ Symbol } & \multicolumn{3}{|c|}{ Island } & \multirow{2}{*}{ Total } \\
\hline & & Koror & Malakal & Ngerekebesang & \\
\hline & & 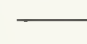 & -1 & tares (acres) & 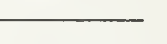 \\
\hline \multicolumn{6}{|l|}{ Forest } \\
\hline Upland forest & UP & 56 & 26 & 119 & 201 \\
\hline Swamp forest & SW & 15 & 0 & 0 & $15(37)$ \\
\hline Mangrove forest & $\mathrm{MN}$ & 189 & 0 & 16 & $205(507)$ \\
\hline Plantation forest & $\mathrm{PF}$ & 2 & 0 & 0 & $2(5)$ \\
\hline Rock Island forest & RI & 206 & 3 & 1 & $210(519)$ \\
\hline Palm forest & $\mathrm{PO}$ & $<1$ & 0 & 0 & $<1$ (1) \\
\hline Total forest & & 468 & 29 & 136 & $633(1,564)$ \\
\hline Secondary vegetation & SV & 54 & 11 & 14 & 79 (195) \\
\hline \multicolumn{6}{|l|}{ Agroforest } \\
\hline Agroforest (w/coconut) & AG.CO & 0 & 0 & 6 & $6(15)$ \\
\hline Total agroforest & & 0 & 0 & 6 & $6(15)$ \\
\hline \multicolumn{6}{|l|}{ Nonforest } \\
\hline Marsh, fresh & M.F & 0 & 0 & $<1$ & $<1(1)$ \\
\hline Marsh, cultivated & M.C & 2 & 0 & 0 & $2(5)$ \\
\hline Grassland & G & 9 & 2 & 42 & $53(131)$ \\
\hline Cropland & $\mathrm{C}$ & 47 & 0 & 12 & $59(146)$ \\
\hline $\begin{array}{l}\text { Cropland/secondary } \\
\text { vegetation }\end{array}$ & $\mathrm{C} / \mathrm{SV}$ & 28 & 0 & 0 & $28(69)$ \\
\hline Urban & $\mathrm{U}$ & 146 & 38 & 38 & $222(548)$ \\
\hline Urban/cropland & $\mathrm{U} / \mathrm{C}$ & 70 & 0 & 0 & $70(173)$ \\
\hline $\begin{array}{l}\text { Urban/secondary } \\
\text { vegetation }\end{array}$ & $\mathrm{U} / \mathrm{SV}$ & 3 & 0 & 0 & $3(7)$ \\
\hline Barren & B & 0 & 5 & 0 & $5(12)$ \\
\hline Water & W & 9 & $<1$ & 0 & $9(22)$ \\
\hline Total nonforest & & 314 & 45 & 92 & $451 \quad(1,114)$ \\
\hline Total area & & 836 & 85 & 248 & $1,169(2,888)$ \\
\hline
\end{tabular}

\section{SURVEY METHODS}

Palau's vegetative types were identified and delineated on photographs taken in 1976, at a scale of 1:10,000. The minimum area mapped during the project was 0.4 ha ( 1 acre). Updating the photos to account for recent changes was not possible. Field work in 1985, however, showed that the vegetation maps are fairly accurate.

Vegetation types were identified by examining the photos stereoscopically for differences in tone, texture, and pattern. In some cases, individual species were recognized by their distinctive shapes. The accuracy of the vegetative typing depended on the age and quality of the photographs, the skill and training of the photo interpreter, and on comparisons of potential types to actual field characteristics.

Before mapping could begin, a vegetative mapping scheme was needed. Since much of the islands are inaccessible by road and because funds were limited, the types defined were restricted to those easily interpreted without intensive ground checking. Type characteristics delineated were limited to those useful to foresters and land-use planners.

After field reconnaissance, the vegetation coding system presented in this bulletin was adopted. The photos were then edited and sent to the Engineering Geometronics Section of the Forest Service's Pacific Southwest Regional Office, for transfer to base maps and for measurement of type areas.

\section{TYPE CLASSIFICATIONS}

For mapping purposes, the islands of Palau were divided into four major land classes-forest, secondary vegetation, agroforest, and nonforest. 
Table 4-Area of the coral islands of Peleliu, Angaur, Kayangel, Republic of Palau, by island, land class, and type, 1979

\begin{tabular}{|c|c|c|c|c|c|}
\hline \multirow{2}{*}{$\begin{array}{l}\text { Land class } \\
\text { and type }\end{array}$} & \multirow{2}{*}{ Symbol } & \multicolumn{3}{|c|}{ Island } & \multirow{2}{*}{ Total } \\
\hline & & Peleliu & Anguar & Kayangel & \\
\hline & & $\longrightarrow$ & - Hectc & ares (acres) & \\
\hline \multicolumn{6}{|l|}{ Forest } \\
\hline Swamp forest & SW & 38 & 9 & 0 & 47 (116) \\
\hline Mangrove forest & $\mathrm{MN}$ & 435 & 0 & 0 & $435(1,075)$ \\
\hline Limestone forest & LI & 587 & 588 & 0 & $1,175(2,903)$ \\
\hline Casuarina & $\mathrm{CA}$ & 404 & 47 & 0 & $451 \quad(1,114)$ \\
\hline Atoll & AT & 1 & 51 & 45 & $97(240)$ \\
\hline Total forest & & 1,465 & 695 & 45 & $2,205(5,448)$ \\
\hline Secondary vegetation & SV & 96 & 31 & 4 & $131(324)$ \\
\hline \multicolumn{6}{|l|}{ Agroforest } \\
\hline Agroforest & AG & 2 & 0 & 0 & $2(5)$ \\
\hline Agroforest (w/coconut) & AG.CO & 0 & 0 & 100 & $100(247)$ \\
\hline Total agroforest & & 2 & 0 & 100 & $102(2,298)$ \\
\hline \multicolumn{6}{|l|}{ Nonforest } \\
\hline Marsh, fresh & M.F & 27 & 0 & 0 & $27(67)$ \\
\hline Marsh, cultivated & M.C & 16 & 9 & 0 & $25(63)$ \\
\hline Marsh, saline & M.S & 25 & 0 & 0 & $25(63)$ \\
\hline Grassland & G & 0 & $<1$ & 1 & $1(3)$ \\
\hline Strand & $S$ & 2 & 0 & 8 & $10(25)$ \\
\hline Cropland & C & 3 & 0 & I & $4(10)$ \\
\hline Urban & $\mathrm{U}$ & 26 & 7 & $<1$ & $33(82)$ \\
\hline Urban/agroforest & $\mathrm{U} / \mathrm{C}$ & 10 & 51 & 0 & $61(151)$ \\
\hline Barren & B & 13 & 13 & 0 & $26(64)$ \\
\hline Water & W & 13 & 4 & $<1$ & $17(42)$ \\
\hline Total nonforest & & 135 & 84 & 10 & $229(566)$ \\
\hline $\begin{array}{l}\text { Total area } \\
\text { (coral islands) }\end{array}$ & & 1,698 & 810 & 159 & $2,667 \quad(6,590)$ \\
\hline
\end{tabular}

Forest-The forest class consists of eight types of areas vegetated with live trees. The Rock Island forest type is a subtype of limestone forest.

Upland forest (UP)

Swamp forest (SW)

Mangrove forest $(\mathrm{MN})$

Atoll forest (AT)

Casuarina forest (CA)

Limestone forest (LI)

Rock Island forest subtype (RI)

Plantation forest (PF)

Palm forest (PO)

Secondary vegetation (SV) - Secondary vegetation includes vines, shrubs, and small trees on recently disturbed areas. In Palau, Macaranga carolinensis and Bambusa spp. are important components of secondary vegetation.

Agroforest (AG) - The agroforest class is made up of areas under cultivation for fruit and other food crops, and trees and wood products. Primary types in this class are:

Agroforest with coconuts (AG.CO)

Coconut plantation (CO)

Nonforest-Nonforest areas consist of lands that have never supported forests or are currently developed for nonforest uses. Seven types are included:
Marsh (M)

Grassland or savanna $(\mathrm{G})$

Strand (S)

Cropland (C)

Urban (U)

Barren (B)

Water (W)

The forest class and coconut plantation type were further subdivided into size and density classes (table 2), identified by these codes:

\begin{tabular}{cl} 
Code & \multicolumn{1}{c}{ Size class } \\
\hline 0 & $\begin{array}{l}\text { Short, shrub-like stands smaller than } 12.5 \mathrm{~cm}(5 \mathrm{in}) \text { in diameter at } \\
\text { breast height (d.b.h.) }\end{array}$ \\
1 & $\begin{array}{l}\text { Trees averaging less than } 30 \mathrm{~cm}(12 \mathrm{in}) \text { in d.b.h., but larger than or } \\
\text { equal to } 12.5 \mathrm{~cm}(5 \mathrm{in}) \text { in d.b.h. }\end{array}$ \\
2 & $\begin{array}{l}\text { Trees averaging } 30 \mathrm{~cm}(12 \text { in) or more in d.b.h. } \\
\text { Code }\end{array}$ \\
\hline H & High-crown closure of main canopy greater than 70 percent. \\
M & Medium-crown closure of main canopy between 30 and 70 percent. \\
L & Low-crown closure of main canopy less than 30 percent.
\end{tabular}

On the folded maps, vegetative areas are numbered and identified by symbols in the legend. In each code, the vegetation type is shown first, followed by the size class and density class. For example, $\mathrm{MN} 1 \mathrm{H}$ would indicate mangrove between $12.5 \mathrm{~cm}(5$ in) and $30 \mathrm{~cm}$ (12 in) in diameter with a dense crown closure. Where possible, predominant species are identified. In such cases, the type code is followed by a period, followed by the first letter of the genus name, as in MN1H.S when Sonneratia makes up at least 20 percent of the mangrove stand. Occasionally, twostoried stands have been identified, usually with a sparse main canopy and an understory of secondary vegetation. For example, UP2L/SV.H would indicate a scattered overstory of upland species overtopping secondary vegetation (table 7 ) that is at least 20 percent Hibiscus.

\section{VEGETATION TYPE DESCRIPTIONS}

A detailed description of the primary types found in each of the major land classes is listed below. Classes are described by habitat and major overstory and understory species. A partial list of Palauan plant species is presented in table 8.

\section{Forest}

Although the Palauan islands at one time may have been completely covered with native forest, they are now only 75 percent forest. Most of the remaining land is classed as grassland, agro- 


\begin{tabular}{|c|c|c|c|c|c|c|}
\hline \multirow{2}{*}{$\begin{array}{l}\text { Land class } \\
\text { and type }\end{array}$} & \multirow[b]{2}{*}{ Symbol } & \multicolumn{4}{|c|}{ State } & \multirow[b]{2}{*}{ Total } \\
\hline & & Airai & Koror & $\begin{array}{l}\text { Ngere- } \\
\text { chelong }\end{array}$ & Peleliu & \\
\hline \multicolumn{7}{|l|}{ Forest } \\
\hline Rock Island forest & RI & 191 & 593 & 0 & 18 & $802(1,982)$ \\
\hline Mangrove forest & $\mathrm{MN}$ & 1 & 0 & 2 & 40 & $43(106)$ \\
\hline Limestone forest & $\mathrm{LI}$ & 0 & 0 & 0 & 57 & $57(141)$ \\
\hline Swamp forest & SW & 0 & 0 & 0 & 1 & $1(2)$ \\
\hline Atoll & $\mathrm{AT}$ & 0 & 0 & 0 & 58 & $58(143)$ \\
\hline Total forest & & 192 & 593 & 2 & 174 & $961 \quad(2,375)$ \\
\hline Secondary vegetation & SV & 2 & 0 & 0 & 0 & $2(5)$ \\
\hline \multicolumn{7}{|l|}{ Agroforest } \\
\hline Agroforest & $\mathrm{AG}$ & 0 & 0 & 0 & 6 & $6(15)$ \\
\hline Coconut & $\mathrm{CO}$ & 0 & 0 & 6 & 65 & $71(175)$ \\
\hline Total agroforest & & 0 & 0 & 6 & 71 & $77(190)$ \\
\hline \multicolumn{7}{|l|}{ Nonforest } \\
\hline Strand ${ }^{1}$ & S & 0 & 0 & 0 & 1 & I (2) \\
\hline Urban & $\mathrm{U}$ & 0 & 1 & 0 & 0 & $1(2)$ \\
\hline Grassland & $\mathrm{G}$ & 0 & 1 & 0 & 0 & I (2) \\
\hline Water & W & 1 & 6 & 0 & 0 & $7(17)$ \\
\hline Total nonforest & & 1 & 8 & 0 & 1 & $10(24)$ \\
\hline Total area & & 195 & 601 & 8 & 246 & $1,050(2,595)$ \\
\hline
\end{tabular}

Includes 0.4 ha of saline marsh.

forest, or secondary vegetation. Almost all of the agroforest and secondary vegetation was once forest land, but the origins of the grasslands are less sure. During the Japanese administration (1914-1945), large areas in southern Babelthuap were cleared of native forest for pineapple and sugar cane fields. During the same period, bauxite mining in Ngardmau State, on the northwest coast destroyed native forest. Whatever their origins, however, most of the grassland area is not yet too eroded and infertile to support forest growth.

\section{Upland Forest (UP)}

Upland forests are found on the volcanic, high islands of Babelthuap, Malakal, Koror, and Ngerekebesang. Most of the other islands of Palau are limestone or coral and support limestone, rock island, or atoll forest types.

The upland forests of Palau are the most species diverse in Micronesia, and include a number of species endemic to Palau. While many interesting ecological communities are present within the upland forests they could not be consistently identified on the photographs, and therefore were not mapped.

One of the most common tree species found in Palau, as in the rest of the Caroline Islands, is Campnosperma brevipetiolata. It is usually found growing at elevations less than $150 \mathrm{~m}(500$ ft) on flat or gently sloping sites and along rivers and streams. Other major species found in Palau's upland forests include Parinari corymbosa, Alphitonia carolinensis, Rhus taitensis, Elaeo- carpus carolinensis, Serianthes kanehirae, Semecarpus venenosus, Calophyllum inophyllum, Gmelina palawensis, and Pterocarpus indicus. Many other tree species occupy the upper canopy in Palauan upland forests.

Species commonly found in the understory of Palau's forests include palms, especially Pinanga insignis and other plants, including Pandanus aimiriikensis, Ixora casei, Engenia cuminii, Osmoxylon oliveri, Manilkara udoido, Symplocos racemosa, and Cyathea lunulata.

\section{Swamp Forest (SW)}

Swamp forests occur where soils are inundated with fresh or slightly brackish water. The most common habitat for such forests is in low lying areas, just inland of mangroves, above tidal influences. Coastal lowland swamps of Palau are generally quite disturbed, with Hibiscus tiliaceus being a common component after disturbance. Taro cultivation is a common competing land use for these swamp areas and is probably the main reason for the clearing of swamp forest.

In Palau, species common to swamps on the landward side of mangroves and along rivers include Horsfieldia amklaal, $C y$ nometra ramiflora, Calophyllum soulattri, Barringtonia racemosa, Heritiera littoralis, Samadera indica, and in the understory, Stemonurus ammui. The climbing vine Derris trifoliata is commonly found growing on trees.

A swamp forest association which is common to low areas of 
impeded drainage is the Horsfieldia amklaal, Barringtonia racemosa, and Donax canniformis type, first described by Hosokawa (1952). This type of swamp forest is not restricted to coastal areas but is quite commonly found along streams in the interior hills of Babelthuap. Horsfieldia trees in these upland swamp areas occasionally attain diameters over $100 \mathrm{~cm}$ (39 in).

Some remnants of swamp forest occur on Peleliu. Species commonly found in these wet areas are Barringtonia racemosa and Terminalia catappa. On Angaur, Barringtonia racemosa, Hibiscus tiliaceus, and Areca catechu (betelnut) grow in a swampy area that remains near the airstrip.

\section{Mangrove Forest (MN)}

In mangrove forests, tree roots are periodically inundated with sea water. They serve as a natural filtering and nutrient buffering system between high islands and lagoons, settling silt and providing a slow sustained release of nutrients into the lagoon. Mangroves also serve as fish spawning grounds and habitat for birds and fruit bats, and provide lumber, firewood, and fisheries.

In Palau, the mangrove forest type occurs along lower portions of rivers and their mouths, on coastal mud flats, and on some offshore islets. Where well developed, stands may reach 15 to $20 \mathrm{~m}$ (50 to $70 \mathrm{ft}$ ).

Although large mangrove trees can be found, Palauan mangroves typically grow in stands of medium-sized trees (MN1). In the interior of large mangrove areas, however, dense stands of short, small trees may be found (MNO)-especially in areas where the water circulation is limited and the soil is relatively firm. The presence of a hard-pan layer of organic material is probably responsible for the stunted growth. Rhizophora spp. predominate in MN0 stands but Bruguiera gymnorrhiza is occasionally found. Individual trees are typically 2 to $3 \mathrm{~m} \mathrm{(7} \mathrm{to} 10$ $\mathrm{ft}$ ) tall and less than $8 \mathrm{~cm} \mathrm{(3} \mathrm{in)} \mathrm{in} \mathrm{d.b.h.--} \mathrm{too} \mathrm{small} \mathrm{to} \mathrm{be} \mathrm{usable}$ for wood products.

Sonneratia alba and Rhizophora mucronata are dominant on the seaward side of the mangrove (Stemmermann and Proby 1978). At the mouths of larger rivers or around bay indentations, Rhizophora mucronata and $R$. apiculata may grow in pure stands or mixed with Sonneratia and some Bruguiera. On the landward side of mangroves, the species mix may include Lumnitzera littorea and Xylocarpus granatum. Where estuaries become riverlike, Rhizophora spp. are rarely found, Sonneratia remains common, and Bruguiera, Xylocarpus, and Lumnitzera become common.

Heritiera littoralis is found along the landward side of mangroves and upstream. Stands of Nypa fruticans occur along the lower portions and mouths of some rivers. Although Nypa palm is fairly common, it generally grows in stringers too narrow to map.

The mangroves of Babelthuap Island are well developed, especially on the south and southwest coasts. The mangroves of Peleliu Island are generally stunted and less dense than those of Babelthuap. One mangrove stand is in Kayangel Atoll, along the shore of a saltwater pond in the interior of a small islet adjacent to Kayangel Island proper. These Bruguiera and Rhizophora trees, now 5 to $6 \mathrm{~m}$ ( 16 to $20 \mathrm{ft}$ ) tall, were planted by the Palau Department of Agriculture and Forestry in the mid 1970's.

\section{Atoll Forest (AT)}

The atoll forest type generally is found towards the interior of larger and wetter uninhabited atolls and along sandy or rocky coasts of high islands. Although generally located behind the strand, atoll forest species are often mixed with the strand species, so the transition from strand to atoll forest is often gradual and indefinite.

Species commonly found in atoll forests include an outer fringe of shrubby Scaevola taccada, occasionally with Tournefortia argentea and Sophora tomentosa. On rocky coasts, Pemphis acidula is common. Both Tournefortia and Pemphis grow into small well-formed trees. Tall Casuarina litorea trees may be present, especially along the leeward shore. Other species include Calophyllum inophyllum, Cordia subcordata, Hernandia sonora, Guettarda speciosa, Pandanus spp., Pisonia grandis, Terminalia catappa, Morinda citrifolia, Neisosperma oppositifolia, Hibiscus tiliaceus, Ficus spp., and Premna obtusifolia.

Human activity has altered the vegetation throughout Micronesia. Agroforest now predominates on most atolls, especially the inhabited ones. Atoll forest has largely disappeared except on uninhabited atolls and sandy or limestone coasts.

\section{Casuarina Forest (CA)}

In a number of places, especially along coastal areas of Peleliu and Angaur, dense stands of Casuarina litorea trees can be found. Although such areas are not well-developed forest communities, they are distinct on aerial photos and readily identified. Where such stands exist, the ground is covered with a thick carpet of fallen needles. This layer of needles tends to inhibit other growth, resulting in the habitat characteristic of Casuarina stands. Larger, relatively pure stands of Casuarina trees are delineated as $\mathrm{CA} 1 \mathrm{H}$. Where sparse in density, Casuarina may also be a component of other types such as atoll forest (AT), limestone forest (LI), or secondary vegetation (SV).

\section{Limestone Forest (LI)}

This is a vegetation type found mainly on the coral islands of Peleliu, Angaur, and the Rock Islands. The species composition of LI varies on the different islands, there being a number of endemic species present. The limestone forest habitat, however, is similar on all islands, supporting both scrubby and tall trees sometimes growing out of bare rock. The humus from decaying leaves and other debris provide a sustained cycling of nutrients. Species commonly found in the limestone forest include Intsia bijuga, Psychotria spp., and Clerodendrum inerme.

Native limestone forest once covered much of Peleliu. However, the vegetation of the island was greatly disturbed during World War II. Less disturbed limestone forest occurs in the mountainous regions of northern Peleliu. Species of this vegetation type, however, are common and can be found scattered throughout the island, and in the secondary vegetation type as well. On Angaur, areas of limestone forest are found interspersed among freshwater, and occasionally, saltwater depressions. These areas are coded LI.SW to indicate the swamp-like condition of the understory. Occasionally, sites are found where 
limestone forest and Casuarina trees (LI.CA) or atoll forest (LI.AT) species grow together (table 4).

\section{Rock Island Forest (RI)}

The Rock Islands of Palau are coralline limestone islands, typically vegetated with Rock Island forest. This forest type is considered a subtype of the limestone forest type (LI), but was mapped separately to indicate the uniqueness of the Rock Islands. In all, 1,117 hectares (2,760 acres) of Rock Island forest

Table 6A-Area by vegetation type for selected Rock Islands, State of Airai, Republic of Palau, 1979

\begin{tabular}{|c|c|c|c|c|c|c|}
\hline \multirow[b]{2}{*}{ Island } & \multicolumn{5}{|c|}{ Vegetation type } & \multirow{2}{*}{ Total area } \\
\hline & $\begin{array}{l}\text { Rock Island } \\
\text { forest } \\
\text { (RI) }\end{array}$ & $\begin{array}{c}\text { Mangrove } \\
\text { forest } \\
(\mathrm{MN})\end{array}$ & $\begin{array}{l}\text { Total } \\
\text { forest }\end{array}$ & $\begin{array}{l}\text { Secondary } \\
\text { vegetation } \\
\text { (SV) }\end{array}$ & Water & \\
\hline \multirow[b]{2}{*}{ Chesechosou } & \multicolumn{6}{|c|}{ Hectares (acres) } \\
\hline & 10 & 0 & 10 & 0 & 0 & $10(25)$ \\
\hline Diebebal & 2 & 0 & 2 & 0 & 0 & $2(5)$ \\
\hline Ngedert & 2 & 0 & 2 & 0 & 0 & $2(5)$ \\
\hline Ngeream & 171 & 1 & 172 & 2 & $<1$ & $174(430)$ \\
\hline Ngkesill & 2 & 0 & 2 & 0 & 0 & $2(5)$ \\
\hline \multirow{2}{*}{$\begin{array}{l}\text { Omelochel } \\
\text { Total area }\end{array}$} & 4 & 0 & 4 & 0 & 0 & $4(10)$ \\
\hline & 191 & 1 & 192 & 2 & $<1$ & $194(479)$ \\
\hline
\end{tabular}

Table 6B-Area by vegetation type for selected Rock Islands, State of Koror. Republic of Palau, 1979

\begin{tabular}{|c|c|c|c|c|}
\hline \multirow[b]{2}{*}{ Island } & \multicolumn{3}{|c|}{ Vegetation type } & \multirow[b]{2}{*}{ Total area } \\
\hline & $\begin{array}{l}\text { Rock Island } \\
\text { forest (RI) }\end{array}$ & $\begin{array}{c}\text { Grassland } \\
\text { (G) }\end{array}$ & $\begin{array}{l}\text { Urban (U), } \\
\text { Water (W) }\end{array}$ & \\
\hline & \multicolumn{4}{|c|}{ Hectares (acres) } \\
\hline Bukrrairong & 13 & 0 & 0 & $13(32)$ \\
\hline ltelblong & 6 & 0 & 0 & $6(14)$ \\
\hline Meduu & 4 & 0 & 0 & $4(9)$ \\
\hline Ngedesakr & 6 & 0 & 0 & $6(15)$ \\
\hline Ngerbechetel & 2 & 0 & 0 & $2(4)$ \\
\hline Ngerchaol & 71 & 0 & 1 & $72(179)$ \\
\hline Ngermalk & 23 & 0 & 1 & $24(60)$ \\
\hline Ngermechaech & 1 & 0 & 0 & $1(3)$ \\
\hline Ngertecheif & 2 & 0 & 0 & $2(4)$ \\
\hline Ngerur & 5 & 0 & 0 & $5(13)$ \\
\hline Ngeteklou & 47 & 0 & 2 & $49(120)$ \\
\hline Ngetkuml & 2 & 0 & 0 & $2(4)$ \\
\hline Ordachel & 6 & 0 & 0 & $6(14)$ \\
\hline Tengetcheyangl & 1 & 0 & 0 & $1(3)$ \\
\hline Torius & 3 & 0 & 0 & $3(7)$ \\
\hline Ucheliungs & 2 & 0 & 0 & $2(6)$ \\
\hline Uchulangas & 2 & 0 & 0 & $2(5)$ \\
\hline Ulebsechl & 394 & 1 & 3 & 398 (985) \\
\hline Ullemetamel & 4 & 0 & 0 & $4(9)$ \\
\hline Total area & 594 & 1 & 7 & $602(1,486)$ \\
\hline
\end{tabular}

Table 6C-Area by vegetation type for selected islands, States of Ngerechelong and Peleliu, Republic of Palau. 1979

\begin{tabular}{|c|c|c|c|c|c|c|c|c|c|}
\hline \multirow[b]{2}{*}{$\begin{array}{l}\text { State } \\
\text { and } \\
\text { island }\end{array}$} & \multicolumn{8}{|c|}{ Vegetation type } & \multirow[b]{2}{*}{ Total area } \\
\hline & $\begin{array}{c}\text { Rock } \\
\text { island } \\
\text { forest } \\
\text { (RI) }\end{array}$ & $\begin{array}{c}\text { Mangrove } \\
\text { forest } \\
\text { (MN) }\end{array}$ & $\begin{array}{l}\text { Lime- } \\
\text { stone } \\
\text { forest } \\
\text { (LI) }\end{array}$ & $\begin{array}{l}\text { Atoll } \\
\text { forest } \\
\text { (AT) }\end{array}$ & $\begin{array}{l}\text { Total } \\
\text { forest }\end{array}$ & $\begin{array}{l}\text { Agro- } \\
\text { forest } \\
(\mathrm{AG})\end{array}$ & $\begin{array}{c}\text { Coco- } \\
\text { nut } \\
(\mathrm{CO})\end{array}$ & $\begin{array}{l}\text { Marsh } \\
\text { and } \\
\text { strand } \\
(\mathrm{M})(\mathrm{S})\end{array}$ & \\
\hline & & & & $-\mathrm{He}_{\mathrm{c}}$ & ares $(a c$ & & & & - \\
\hline \multicolumn{10}{|l|}{ Ngerechelong } \\
\hline Ngerkeklau & 0 & 2 & 0 & 0 & 2 & 0 & 6 & 0 & $8(19)$ \\
\hline \multicolumn{10}{|l|}{ Peleliu } \\
\hline Belualasmau & 0 & 0 & 0 & 2 & 2 & 0 & 0 & 0 & $2(6)$ \\
\hline Ngebad & 0 & ${ }^{1} 11$ & 41 & 4 & 56 & 0 & 0 & 1 & $57(141)$ \\
\hline Ngedbus & 0 & 6 & 0 & 24 & 30 & 0 & 65 & 0 & $95(234)$ \\
\hline Ngerumetochel & 18 & 0 & 0 & 0 & 18 & 0 & 0 & 0 & $18(45)$ \\
\hline Ngesuall & 0 & 0 & 2 & 0 & 2 & 0 & 0 & 0 & $2(4)$ \\
\hline Ngurungor & 0 & 10 & 15 & 0 & 25 & 0 & 0 & 0 & $25(62)$ \\
\hline Olngeuaol & 0 & 9 & 0 & 28 & 37 & 0 & 0 & 0 & $37(92)$ \\
\hline Ruriid & 0 & 4 & 0 & 0 & 4 & 6 & 0 & 0 & $10(25)$ \\
\hline Tengabard! & 0 & 1 & 0 & 0 & 1 & 0 & 0 & 0 & $1(2)$ \\
\hline Total area & 18 & 43 & 58 & 58 & 177 & 6 & 71 & 1 & $255(630)$ \\
\hline
\end{tabular}

'Includes $<1$ ha of swamp forest (SW). 
Table 7-Vegetation type codes used for the islands in the Republic of Palau'

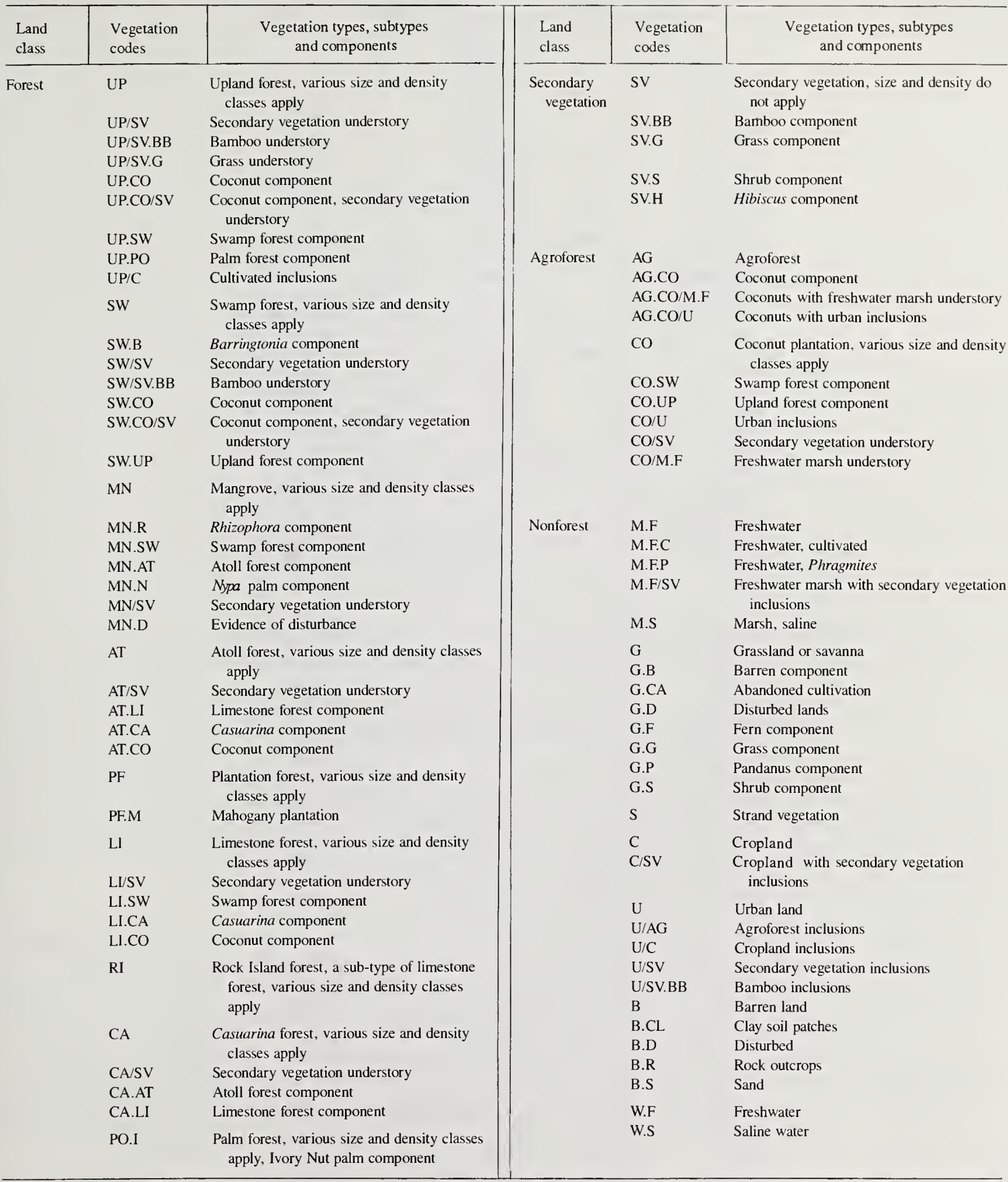

'NOTES:

Size classes and density codes are used only with the forest class and with the coconut plantation type.

Various combinations of components are used, especially within the grassland type, as for G.B.F.P or grassland with barren, fern, and pandanus components.

Each component, inclusion, or understory species identified must be present on at least 20 percent of the mapped area. 


\begin{tabular}{|c|c|c|c|}
\hline Genus & Species & Author & Family \\
\hline Acrostichum & aureum & L. & Pteridaceae \\
\hline Alphitonia & carolinensis & Hosoka & Rhamnaceae \\
\hline Areca & catechu & L. & Palmae \\
\hline Artocarpus & spp. & & Moraceae \\
\hline Bambusa & vulgaris & Schrader & Gramineae \\
\hline Barringtonia & racemosa & (L.) Spreng. & Lecythidaceae \\
\hline Bikkia & palauensis & Val. & Rubiaceae \\
\hline Bruguiera & gymnorrhiza & (L.) Lamarck & Rhizophoraceae \\
\hline Calophyllum & inophyllum & L. & Guttiferae \\
\hline Calophyllum & soulattri & Burm. f. & Guttiferae \\
\hline Campnosperma & brevipetiolata & Volkens & Anacardiaceae \\
\hline Casuarina & litorea & $\mathrm{L}$ & Casuarinaceae \\
\hline Clerodendrum & inerme & (L.) Gaertn. & Verbenaceae \\
\hline Cocos & nucifera & L. & Palmae \\
\hline Cordia & subcordata & Lamarck & Boraginaceae \\
\hline Cyathea & lunulata & (Forst. f.) Copel. & Cyatheaceae \\
\hline Cynometra & ramiflora & Schltr. & Gesneriaceae \\
\hline Cyperus & javanicus & Houtt. & Cyperaceae \\
\hline Decaspermum & spp. & & Myrtaceae \\
\hline Derris & trifoliata & Loureiro & Leguminosae \\
\hline Donax & canniformis & (Forst. f.) Schum. & Marantaceae \\
\hline Dracaena & multiflora & Warb. ex Sarasin & Agavaceae \\
\hline Elaeocarpus & carolinensis & Koidz. & Tiliaceae \\
\hline Eleocharis & geniculata & (L.) Roemr \& Schultes & Cyperaceae \\
\hline Eugenia & cuminii & (L.) Druce & Myrtaceae \\
\hline Eugenia & spp. & & Myrtaceae \\
\hline Eurya & japonica & (Korth.) This.-Dyer & Theaceae \\
\hline Ficus & spp. & & Moraceae \\
\hline Fimbristylis & cymosa & R. Br. & Cyperaceae \\
\hline Garcinia & mangostana & L. & Guttiferae \\
\hline Gleichenia & linearis & (Burm. f.) C.B.CL & Gleicheniaceae \\
\hline Gmelina & palawensis & H. J. Lam & Verbenaceae \\
\hline Guettarda & speciosa & $\mathrm{L}$ & Rubiaceae \\
\hline Gulubia & palauensis & (Becc.) Moore \& Fosb. & Palmae \\
\hline Heritiera & littoralis & Dry. & Sterculiaceae \\
\hline Hernandia & sonora & L. & Hernandiaceae \\
\hline Hibiscus & tiliaceus & L. & Malvaceae \\
\hline Horsfieldia & amklaal & Kanehira & Myristicaceae \\
\hline Intsia & bijuga & (Colebr.)O.Ktze. & Leguminosae \\
\hline Ipomoea & aquatica & Forsskal, Fl. & Convolvulaceae \\
\hline Ipomoea & pes-caprae & (L.) V. Ooststr. & Convolvulaceae \\
\hline Ischaemum & chordatum & (Trin.) Hack. Warb. & Gramineae \\
\hline Ixora & casei & Hance & Rubiaceae \\
\hline Lippia & nodiflora & (L.) Rich. & Verbenaceae \\
\hline Lumnitzera & littorea & (Jack) Voigt & Combretaceae \\
\hline Macaranga & carolinensis & Volk. & Euphorbiaceae \\
\hline Mangifera & indica & $\mathrm{L}$. & Anacardiaceae \\
\hline Manilkara & udoido & Kan. & Sapotaceae \\
\hline Melastoma & malabathricum & (Naudin) Fosb. \& Sachet & Melastomaceae \\
\hline Metroxylon & amicarum & (Wendl.) Becc. & Palmae \\
\hline Miscanthus & floridulus & (Labill.) Warb. & Gramineae \\
\hline Morinda & citrifolia & L. & Rubiaceae \\
\hline Musa & spp. & & Musaceae \\
\hline Neisosperma & oppositifolia & (Lam.) Fosb. \& Sachet & Apocynaceae \\
\hline Nephelium & lappaceum & L. & Sapindaceae \\
\hline Nypa & fruticans & Wurmb. & Palmae \\
\hline Osmoxylon & oliveri & Fosb. \& Sachet & Araliaceae \\
\hline Pandanus & aimiriikensis & Mart. & Pandanaceae \\
\hline Pandanus & spp. & & Pandanaceae \\
\hline Parinari & corymbosa & (Bl.) Miq. & Rosaceae \\
\hline Paspalum & distichum & L. & Gramineae \\
\hline Pemphis & acidula & Forst. & Lythraceae \\
\hline Phragmites & karka & (Retz.) Trin. ex Steud. & Gramineae \\
\hline Pinanga & insignis & Becc. & Palmae \\
\hline
\end{tabular}




\begin{tabular}{|c|c|c|c|}
\hline Genus & Species & Author & Family \\
\hline Pisonia & grandis & R. Brown & Nyctaginaceae \\
\hline Premna & obtusifolia & R. Brown & Verbenaceae \\
\hline Psychotria & spp. & & Rubiaceae \\
\hline Pterocarpus & indicus & Willd. & Leguminosae \\
\hline Ptychosperma & palauensis & (Kaneh.) Moore \& Fosb. & Palmae \\
\hline Rhizophora & apiculata & Blume & Rhizophoraceae \\
\hline Rhizophora & mucronata & Lamarck & Rhizophoraceae \\
\hline Rhus & taitensis & Guillemin & Amacardiaceae \\
\hline Samadera & indica & Graetn. & Simaroubaceae \\
\hline Scaevola & taccada & (Gaertner) Roxburgh & Goodeniaceae \\
\hline Semecarpus & venenosus & Volkens & Anacardiaceae \\
\hline Serianthes & kanehirae & Fosb. & Leguminosae \\
\hline Sonneratia & alba & J. E. Sm. & Sonneratiaceae \\
\hline Sophora & tomentosa & L. & Leguminosae \\
\hline Stemonurus & ammui & (Kaneh.) Sleumer & Icacinaceae \\
\hline Swietenia & macrophylla & King & Meliaceae \\
\hline Swietenia & mahagoni & (L.) Jacq. & Meliaceae \\
\hline Symplocos & racemosa & (Koidz.) Nooteb. & Symplocaceae \\
\hline Terminalia & catappa & L. & Combretaceae \\
\hline Timonius & timon & (Spr.) Merr. & Rubiaceae \\
\hline Tournefortia & argentea & (L.f.) Johnston & Boraginaceae \\
\hline Vigna & marina & (Burm.) Merrill & Leguminosae \\
\hline Wikstroemia & elliptica & Merr. & Thymelaeaceae \\
\hline Xylocarpus & granatum & Koenig & Meliaceae \\
\hline
\end{tabular}

'Dicotyledonae follow Fosberg and others (1979) and Fosberg and others (1980). Palm nomenclature follows that of Moore and Fosberg(1956).

were typed, representing only a fraction of the total area of the Rock Islands. Unfortunately, no photography was available for most of the Rock Islands.

The forest of the Rock Islands is diverse in species composition and varies among islands. Some of the more common species include the native palms Gulubia palauensis and Ptychosperma palauensis, and the forest trees Semecarpus venenosus, Intsia bijuga, Psychotria spp., Premna obtusifolia, Cordia spp., Clerodendrum inerme, and Bikkia palauensis. Pandanus spp. and Dracaena multiflora are also common in the understory.

\section{Plantation Forest (PF)}

Forest plantations are planted for commercial forest production, erosion control, or conversion. The type is limited to experimental species introduction trials near the Nekkeng Forestry Station and to several small plantations, most of which were established during the Japanese era. Various introduced species include Swietenia mahagoni, S. macrophylla, Pterocarpus indicus, and the fruit trees Nephelium lappaceum (rambutan) and Garcinia mangostana.

\section{Palm Forest (P0)}

Although there are six native palms found in Palau, they usually occupy the understory or middle canopy layers of the forest, and do not occur in pure, mappable stands. The only palm forest stand located during the project was on Koror, a 0.4 hectare ( 1 acre) area of the introduced ivory nut palm (Metroxylon amicarum).

\section{Secondary Vegetation}

Areas of fast-growing small trees, shrubs, and vines growing in recently disturbed areas are classified as secondary vegetation. Such areas sometimes represent traditional gardens in a fallow phase. To some extent secondary vegetation functions as a natural "bandage" protecting disturbed soils from Palau's heavy rains, allowing humus and nutrients to accumulate in the soils.

On Palau's volcanic islands, Macaranga carolinensis is the usual component of secondary vegetation. Bambusa is also common. Generally, Hibiscus tiliaceus occurs more commonly on wetter sites, although it can be found growing elsewhere. The impenetrable Hibiscus thickets common to Pohnpei and Kosrae are not found here, except in some wetter areas.

The most common secondary vegetation species found on the limestone islands of Peleliu and Angaur are Macaranga carolinensis and the native limestone species, Timonius timon.

\section{Agroforest}

Agroforests occupy areas generally along the coast and near dwellings and are characterized by a mix of food-producing trees, forest trees, and other plants. These "tree gardens" rep- 
resent a sustainable system of food production and wise use of available resources. The canopy is often uneven and may be interspersed with small taro patches, open canopy gardens, and areas of secondary vegetation - all too small to be mapped separately.

Agroforest with a crown cover of over 20 percent coconut trees (Cocos nucifera) is typed as AG.CO. Other species commonly present include breadfruit (Artocarpus spp.), mango (Mangifera indica), bananas (Musa spp.), Eugenia spp., and betelnut (Areca catechu).

\section{Coconut Plantation (CO)}

In Palau, coconut plantations - geometric grids of planted coconut palms - are relatively common. Most were established in the late 1800 's by the Germans for copra production. On the island of Babelthuap — especially on the sandy east coast - these coconut plantations have been abandoned and are reverting to upland forest. Such areas are coded as either CO.UP or CO/SV, depending upon the size and composition of the associated vegetation.

\section{Nonforest}

\section{Marsh (M)}

Marsh areas are dominated by grasses, sedges, and herbs growing in standing water most of the year. A number of types of marshes are identified, including freshwater and saline:

- Marsh, freshwater (M.F)—Areas just slightly above sea level and surrounded by mangroves, as in the freshwater marsh/ open canopy swamp forest category described by Stemmermann and Proby (1978), or in depressions in upland areas. The vegetation in these areas may include tall reeds, especially Phragmites karka, sedges, and other taller herbaceous growth. Where the water is somewhat brackish, the fern Acrostichum aureum may be present. Freshwater marshes cultivated for taro are coded M.F.C, and here the edible vine Ipomoea aquatica may be found.

- Marsh, saline (M.S) - Areas dominated by herbaceous vegetation growing in salt or brackish water conditions. Saline marshes are generally located along the coast, near mangroves or in depressions in sand or mud flats. Only 0.4 hectare ( $\mathrm{l}$ acre) of saline marsh, on Ngebad Island, was mapped. Other inclusions of saline marsh are too small for mapping. Common species include Cyperus javanicus, Derris trifoliata (especially at the edge of mangroves), Eleocharis geniculata. Fimbristylis cymosa, Lippia nodiflora, Paspalum distichum, and Vigna marina. A number of woody species characteristic of coastal sands, swamp forests, and mangroves may surround or be sparsely scattered in the marshes.

\section{Grassland/Savanna (G)}

Grasslands/savannas are areas of land supporting a layer of herbaceous, fern or low shrub cover. Tall shrubs and trees, if present, are widely scattered. The soils are generally poorly drained clays.
Some of the grasslands/savannas on Babelthuap are a result of human activity - land clearing, mining, or wildfire. Other grasslands/savannas may also be the result of past human disturbance or be a natural occurrence related to the presence of bauxite soils. In any event, the grasslands are maintained by frequent fires that destroy both vegetation and the humus layer of the soil. The combined effects of wind, sun, and heavy rain cause continuing erosion of the degraded soils, insuring that only adapted herbaceous and fern species will survive.

Five major subtypes of grasslands/savannas have been identified: bare, fern lands, grasslands, shrubs, and abandoned agriculture.

- Bare-Areas of patchy herbaceous growth-generally low grasses and sedges - on poor soils. Patches of bare soil are common (designated G.B).

- Fern lands-Areas in which predominant cover is a tangled mat of Gleichenia linearis fern (designated G.F). Such areas are subject to frequent burning and soils are generally heavy, infertile clays. On Babelthuap, this type often replaces the mix of native and introduced shrubs, Pandanus spp., and herbaceous vegetation that is characteristic of savanna in the western Caroline Islands.

- Grasslands-grasslands/savannas with a mixture of graminoid species (designated G.G) may include other associations such as ferns, shrubs, and pandanus. Graminoid species include Ischaemum spp. and Miscanthus floridulus.

- Shrubs-Areas with a mixture of shrubs (designated G.S). Species specific to grasslands/savannas include Eurya japonica. Wikstroemia elliptica, Melastoma malabathricum, and Decaspermum spp.

- Abandoned agriculture-Grasslands/savannas once under cultivation (designated G.CA). Where soils are not so degraded, a number of herbaceous species may be found. In Palau, the most common species is Ischaemum chordatum.

\section{Strand (S)}

The strand type includes herbaceous vegetation or shrubs growing along the ocean shore on a sandy or rocky substrate. This type is usually included with the atoll forest type, since the two are hard to separate. A total of 11 hectares (27 acres) of strand vegetation was mapped on Kayangel, Peleliu, and other small islands of Palau. Herbaceous species include Vigna marina, Ipomoea pes-caprae, and Fimbristylis spp. The small tree Pemphis acidula is also common.

\section{Cropland (C)}

Cropland is cultivated land without tree cover. Most of these gardens are too small to delineate and are included with other types such as agroforest or secondary vegetation.

\section{Barren (B)}

Areas lacking natural vegetation, for such reasons as presence of rocks and sterile soil, are delineated as barren. Many barren areas on Babelthuap Island are abandoned bauxite mines. 


\section{Urban (U)}

Urban areas are those developed for nonforest, nonagricultural use. Where buildings, roads, or similar features are interspersed with vegetation, the area may be classified as urban/ secondary vegetation (U/SV), urban/agroforest (U/AG), or urban/cropland $(\mathrm{U} / \mathrm{C})$.

\section{Water (W)}

Water includes both fresh water and saline pools (W.S).
Nonforest land: Land that has never supported forests; or was formerly forested, but is currently developed for nonforest use.

Secondary vegetation: A vegetation type characterized by small, fast-growing trees and vines, usually weedy invaders.

Vegetation type: An area delineated on the folded maps as having species composition similar to one of the types described in the section on type classification.

\section{GLOSSARY}

\section{REFERENCES}

Agroforest: Land where planted fruit trees and other agricultural plants are cultured among forest trees.

D.b.h.: Diameter at breast height. Tree diameter outside bark measured at breast height, $1.3 \mathrm{~m}$ above the ground.

Forest land: Land at least 10 percent stocked by live trees or land formerly having such tree cover and not currently developed for nonforest use.

Land area: Land area includes dry land and land temporarily or partially covered by water, such as marshes, swamps, and river flood plains.

Land class: A classification of land by major use or major vegetative characteristics, i.e., forest, secondary vegetation, agroforest, and nonforest.

Fosberg, F. Raymond; Sachet, Marie-Helene; Oliver, Royce. A geographical checklist of the Micronesian dicotyledonae. Micronesica 15(1-2): 41-295: 1979.

Fosberg, F. Raymond; Otobed, Demi; Sachet, Marie-Helene; Oliver, Royce; Powell, Dulcie A.; Canfield, Joan E. Vascular plants of Palau with vernacular names. Department of Botany, Smithsonian Institution, Washington DC; 1980.43 p.

Hosokawa, Takashide. A synchrological study of the swamp forests in the Micronesian Islands. Mem. Fac. Sci. Kyushu Univ. Ser. E. 1:101-123; 1952.

Moore, Harold E.; Fosberg, F. Raymond. The palms of Micronesia and the Bonin Islands. Gentes Herbarium 8(6): 423-478; 1956.

Stemmermann, Lani; Proby, Fred. Inventory of wetland vegetation in the Caroline Islands. Vol. I. Honolulu, HI: Pacific Ocean Division, U.S. Army Corps of Engineers; 1978. 231 p. 




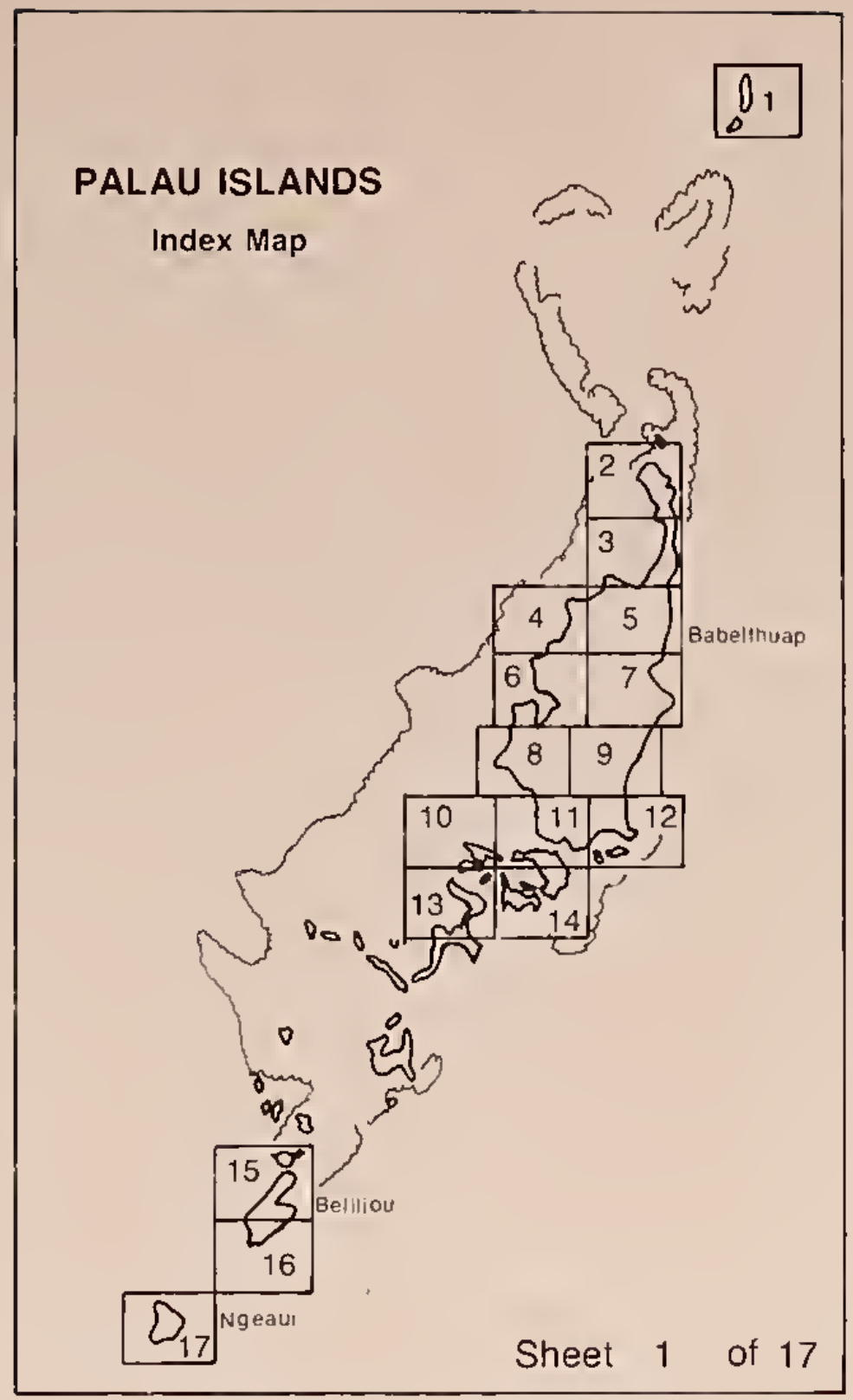

Cote, Tliomas G, Falanruw, Malpone C. MacLean, Cotin D. Whilesell, Claig D. Ambacher, Alan $\mathrm{H}$ Vegelalion surwey of

Ihe Republic ol Palal Resoul 8ull PSW-22 Belkeley, CA

Pacilic Soulhwes! Foles! and Range Expcriment SIation.

Folesl Service, U.S Depariment of Aglicultule, 1987 


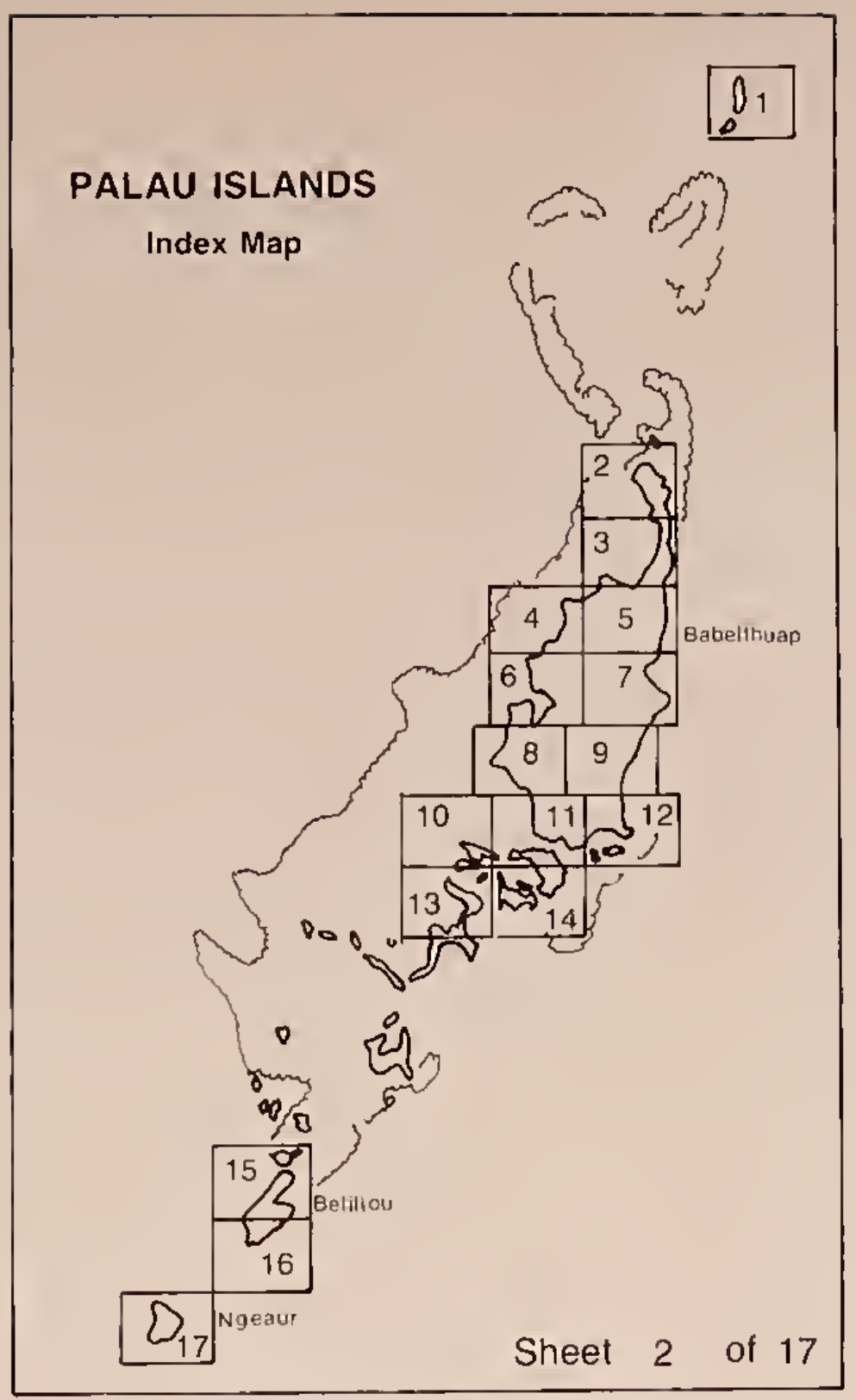

Cole, Thomas G, Falanruw, Marjoure $C$, Machean, Colln D., Whilesoll, Cealg D., Ambacher, Alan $\mathrm{H}$ Vegelalion survey of

the Republlc of Palau. Resour Bull PSW.22. Berkeley, CA

Pacric Southwesi Foresl and Aange Enperiment Slation

Foresl Service, U S. Dopariment ol Agrrcuiture, 1987 


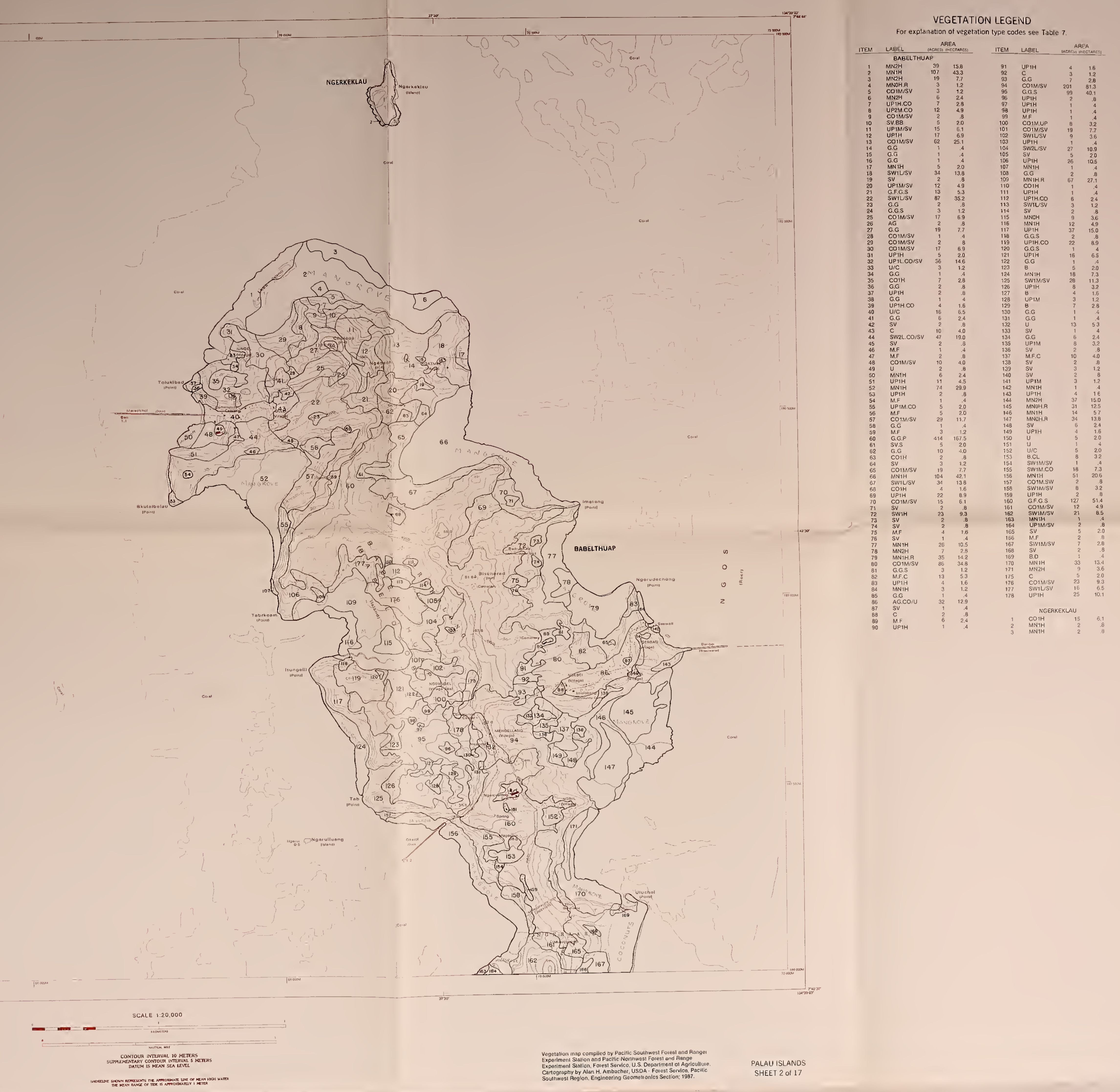




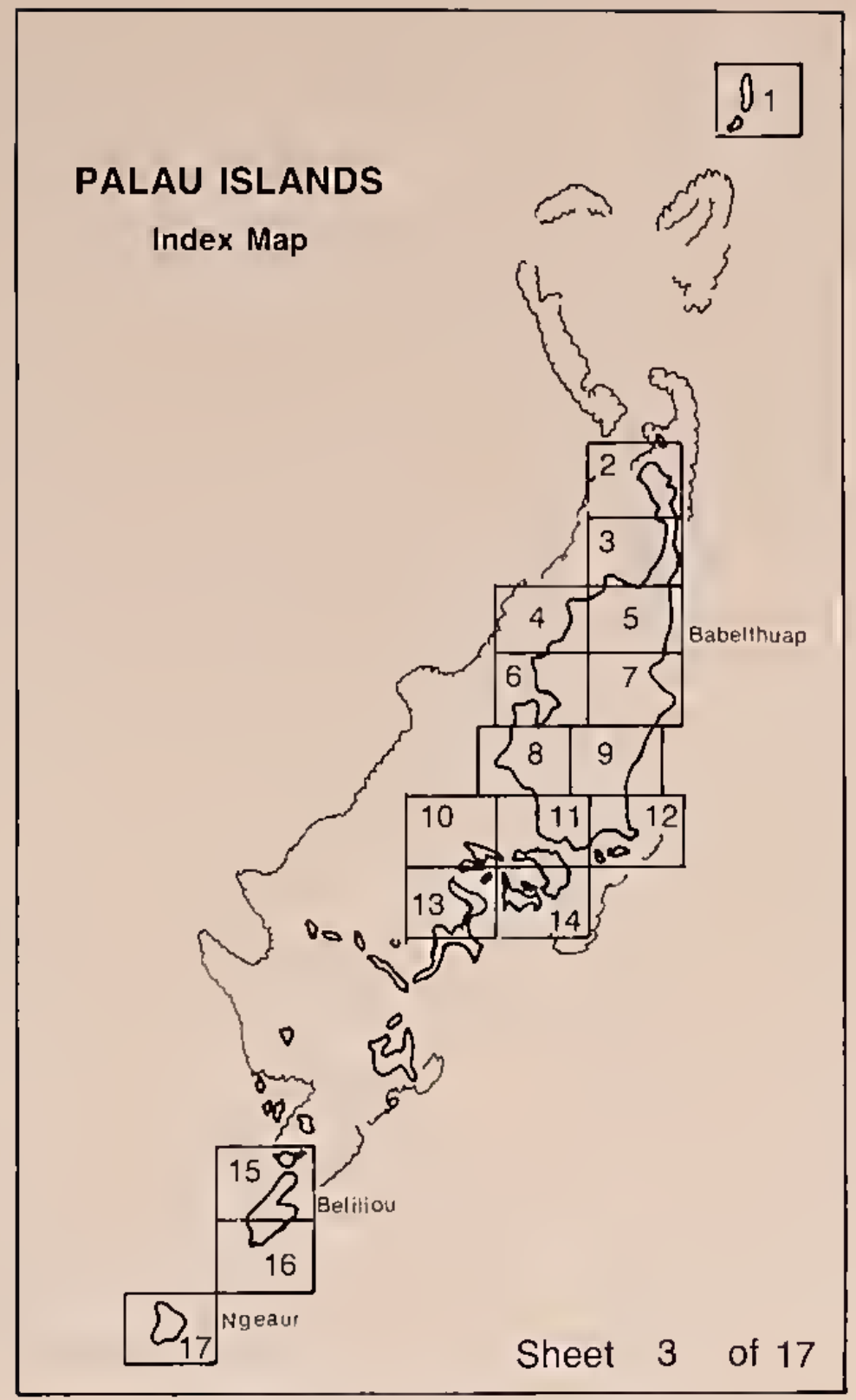

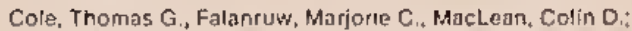
Whilesell, Craig D. Ambacher, Alan H Vegelalion survey of the Republic of Palau. Resour. Buli. PSW.22. Berkeley, CA.

Pacilic Soulnwest Forest and Range Experiment Sialion.

Foresl Service, U.S. Deparlmanl ol Agricullure: 1987 


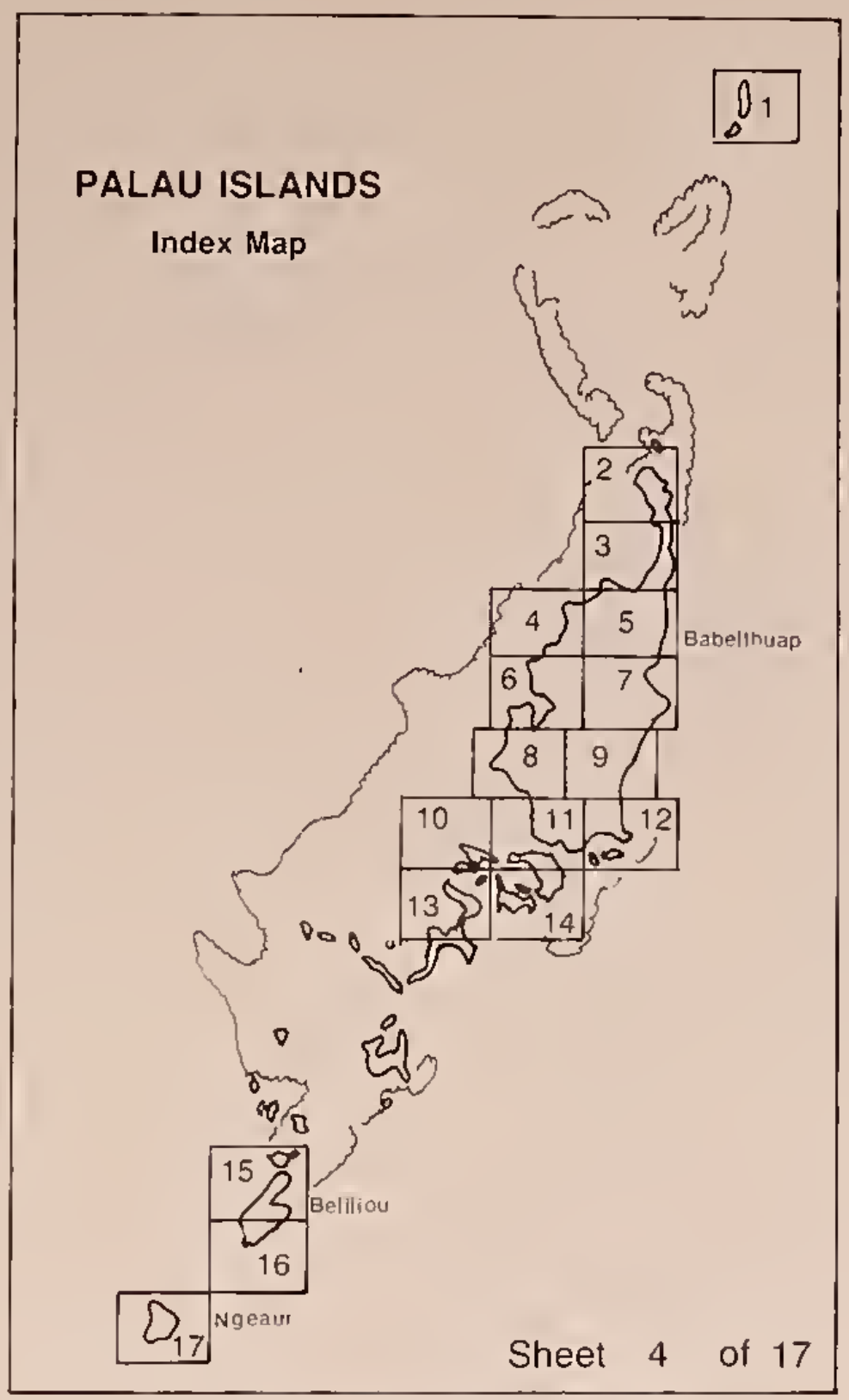

Cole, Thomas $G$, Falanruw, Marjorre C. MacLean, Colrn D. Whilesell, Craig O. Ambacher. Alan $\mathrm{H}$ Vegelation survey of the Republic ol Palau. Resout Bull PSW-22 Berkeley, CA

Pacric Soulnwesl Foresl and Range Experiment Slalion

Folest Service, U D Depariment ol Agriculture, 1987 


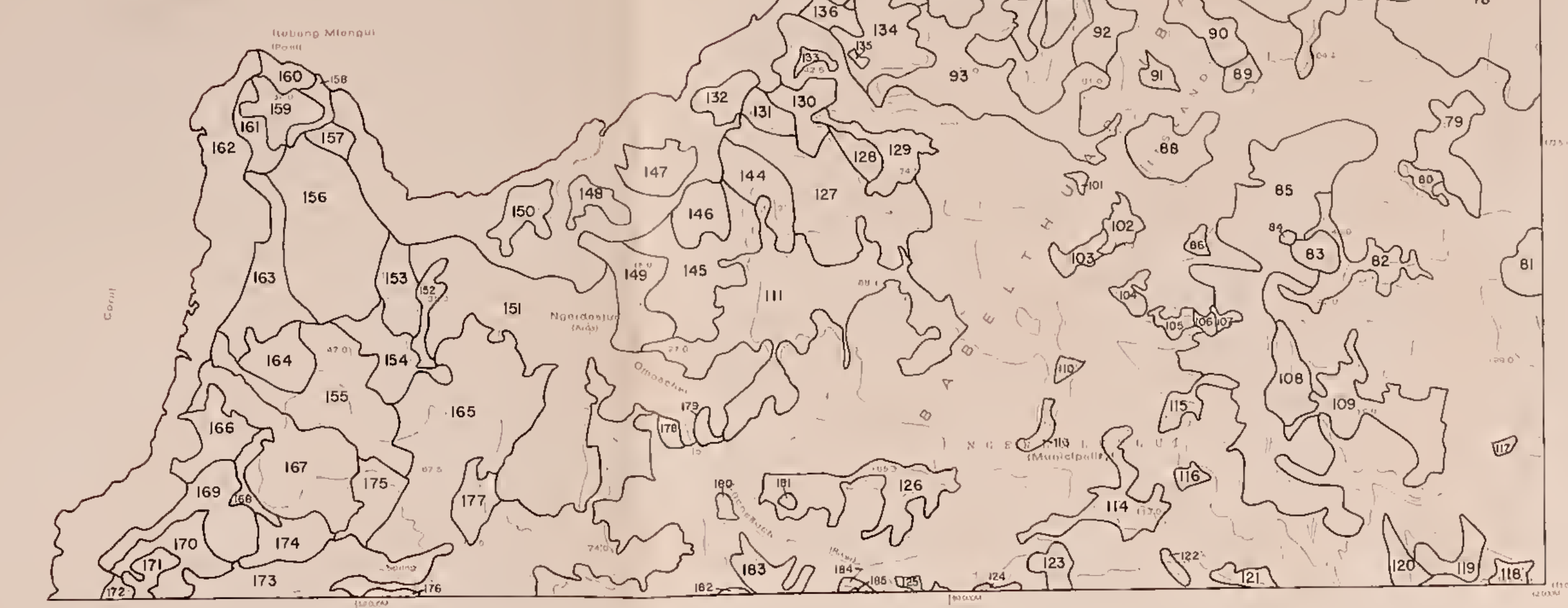

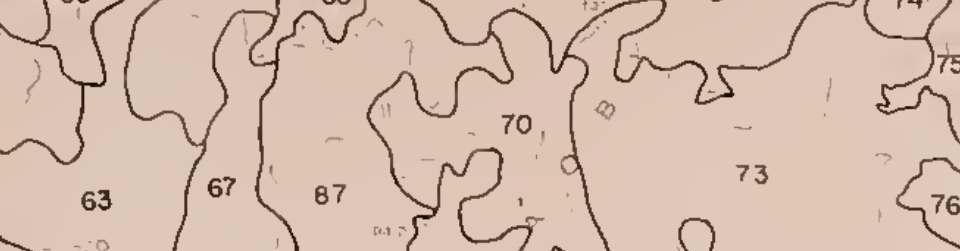
?

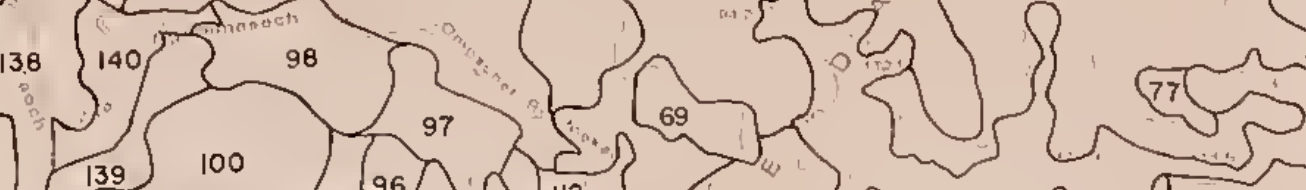

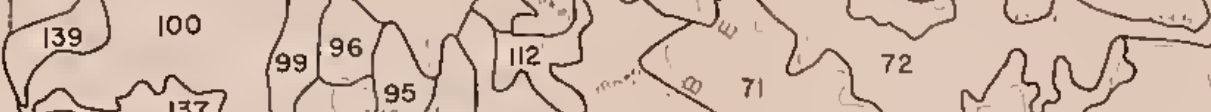

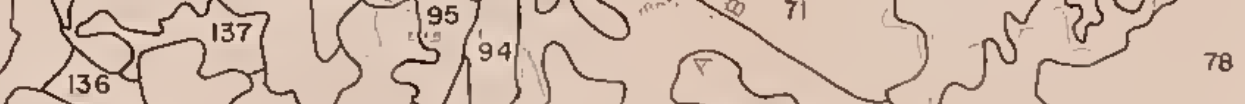

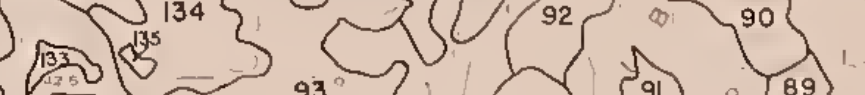
s.

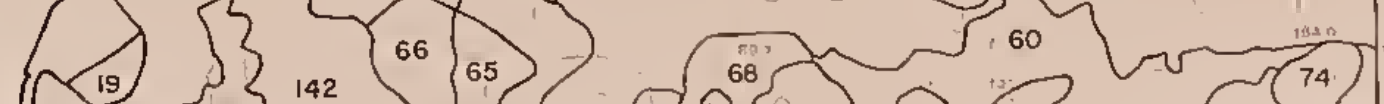




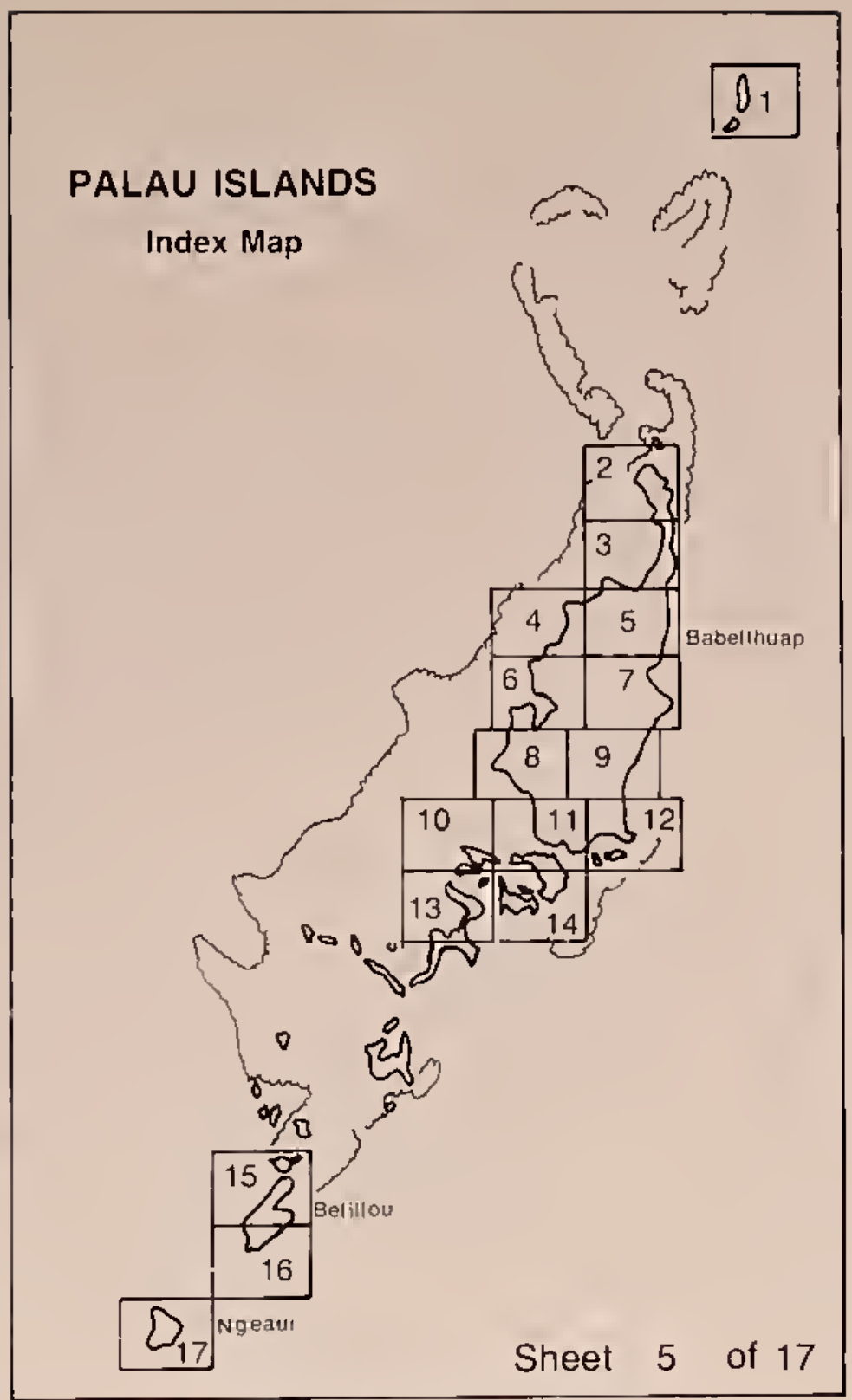

Cole, Thumas G., Falanıuw, Marjolıe C., MacLean, Colın D. Whutesell, Craig $\mathrm{O}$. Ambacher, Alan $\mathrm{H}$ Vagelation survey of

the Republic ol Palau. Resour Bill PSW-22 Berkeley, CA

Pacific Southwesi Foresl and Pange Experimenl Station.

Folest Service, U.S. Depaliment ol Aglleulture, 1987 


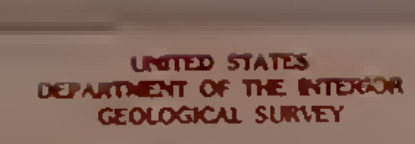

VEEETATION LEEEND

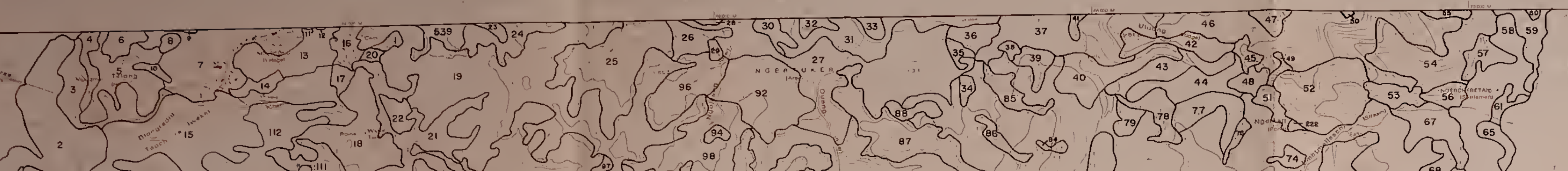

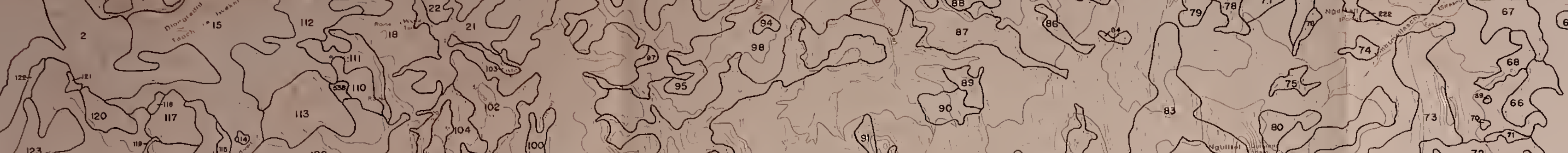

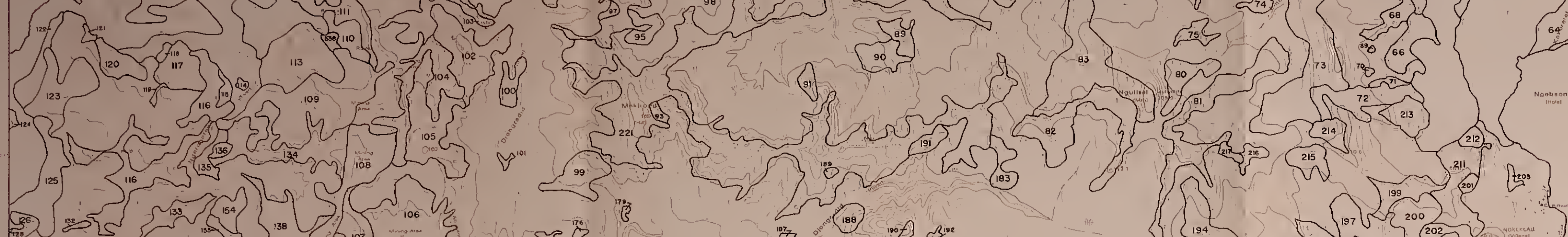
(n) in

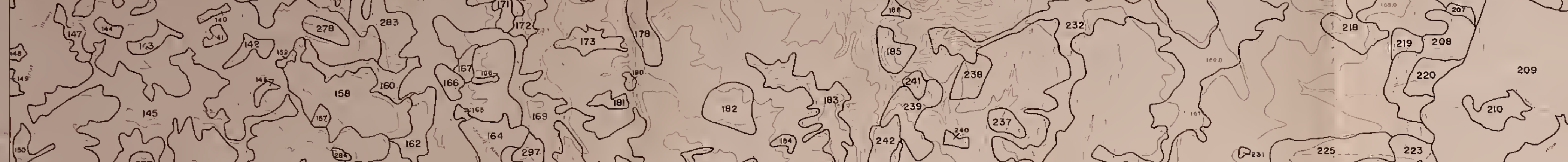

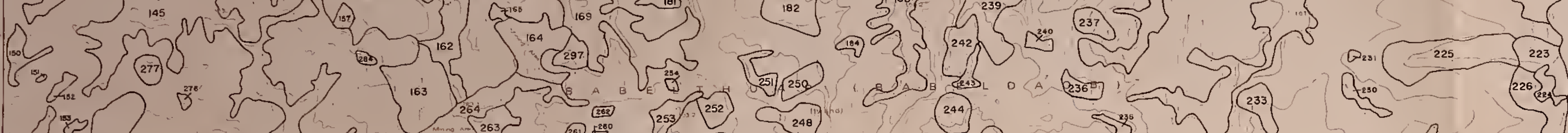

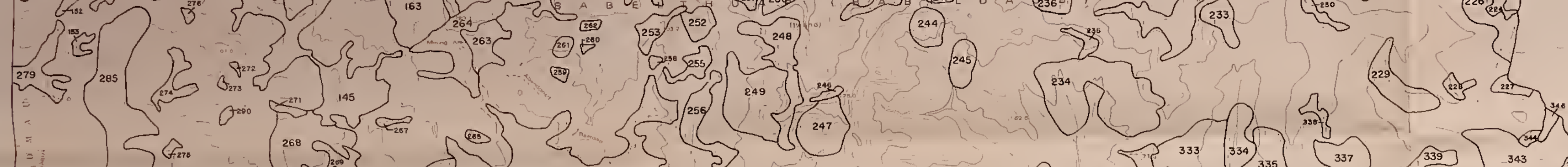
3 (37)

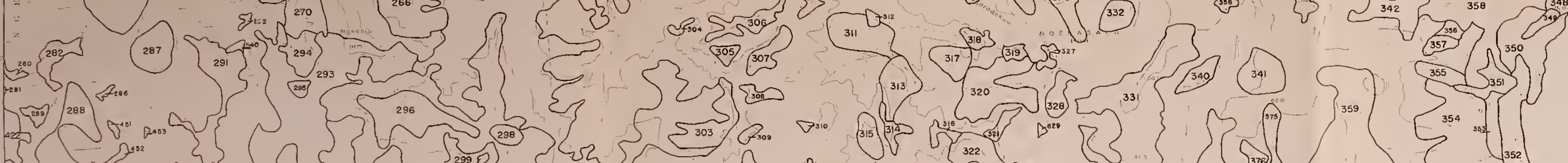

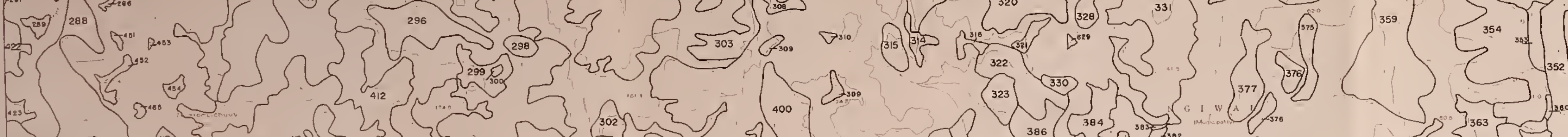

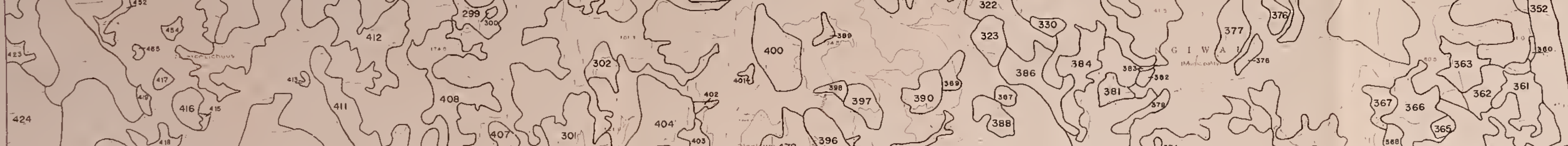

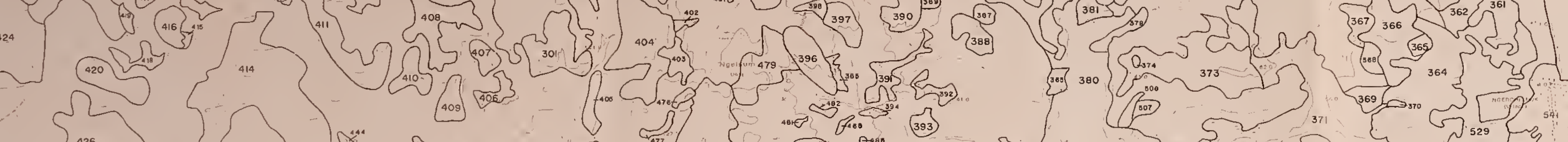
$2\left\{\begin{array}{lll}3 \\ 3\end{array}\right.$ (n) 


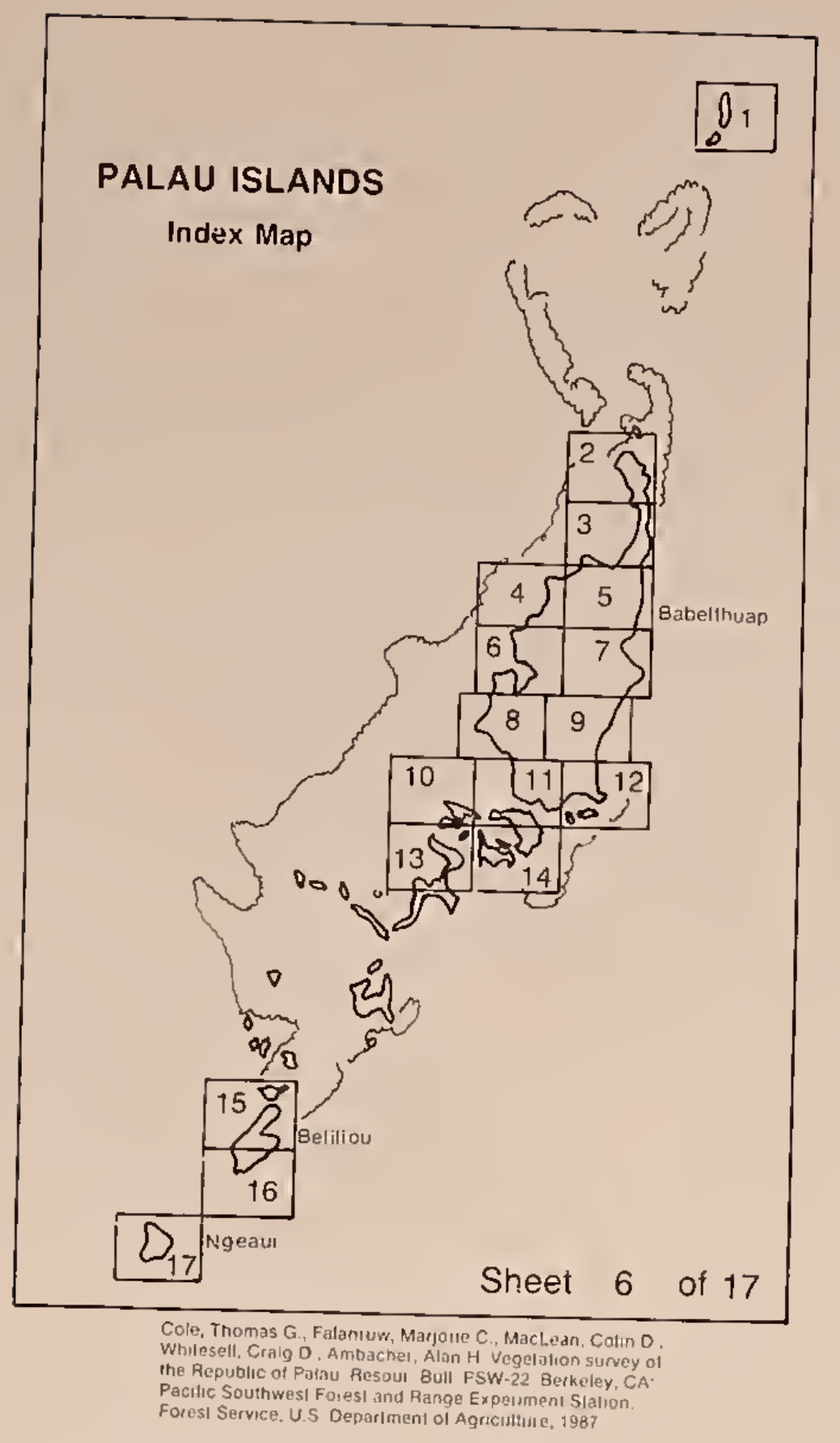




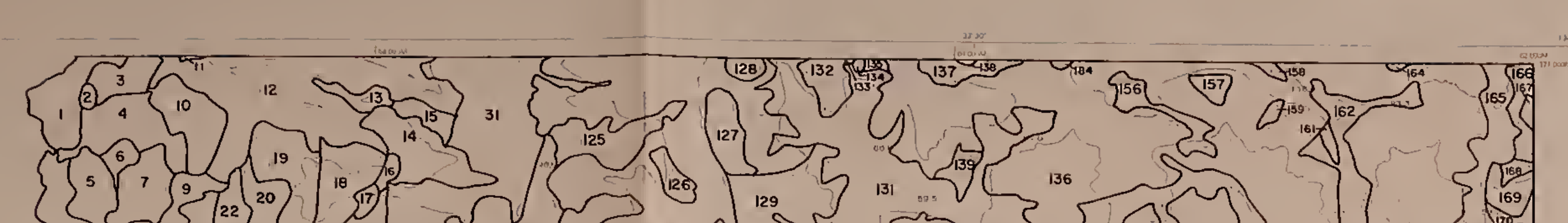

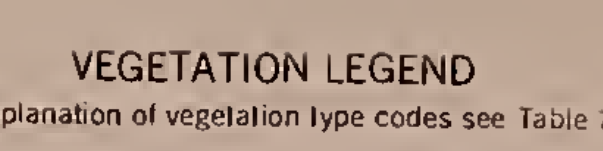
(1) $\{$ (⿻)

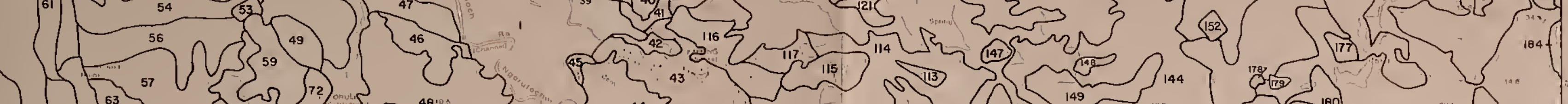
(6)

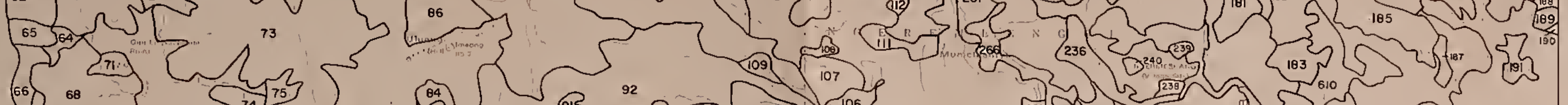

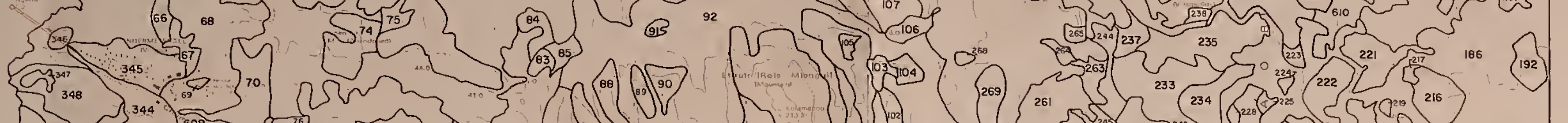

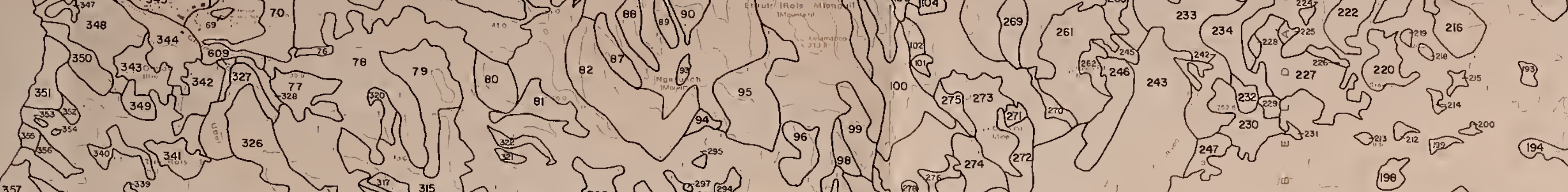
2. (2) तn osaruturer (3) (3).

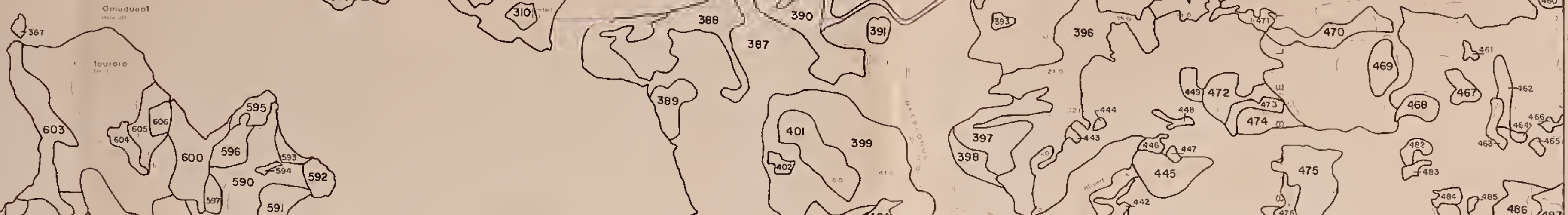
(1)

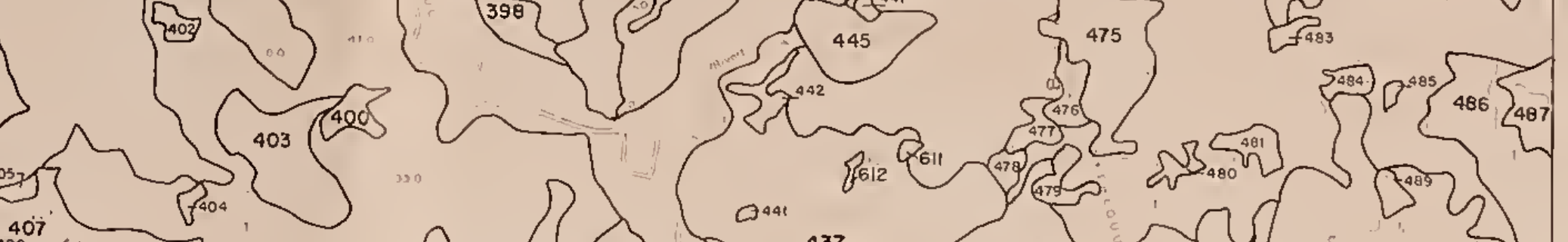

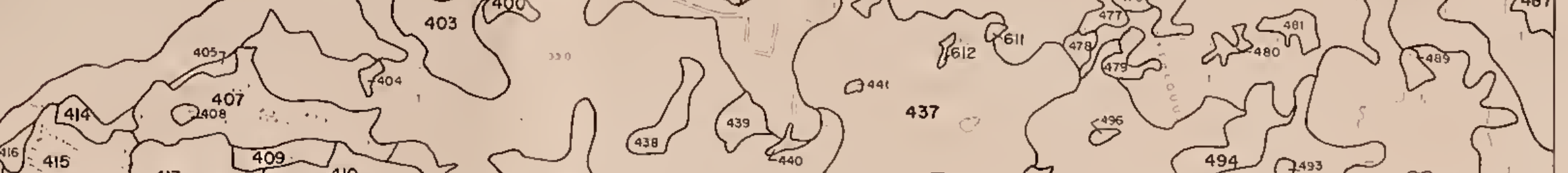
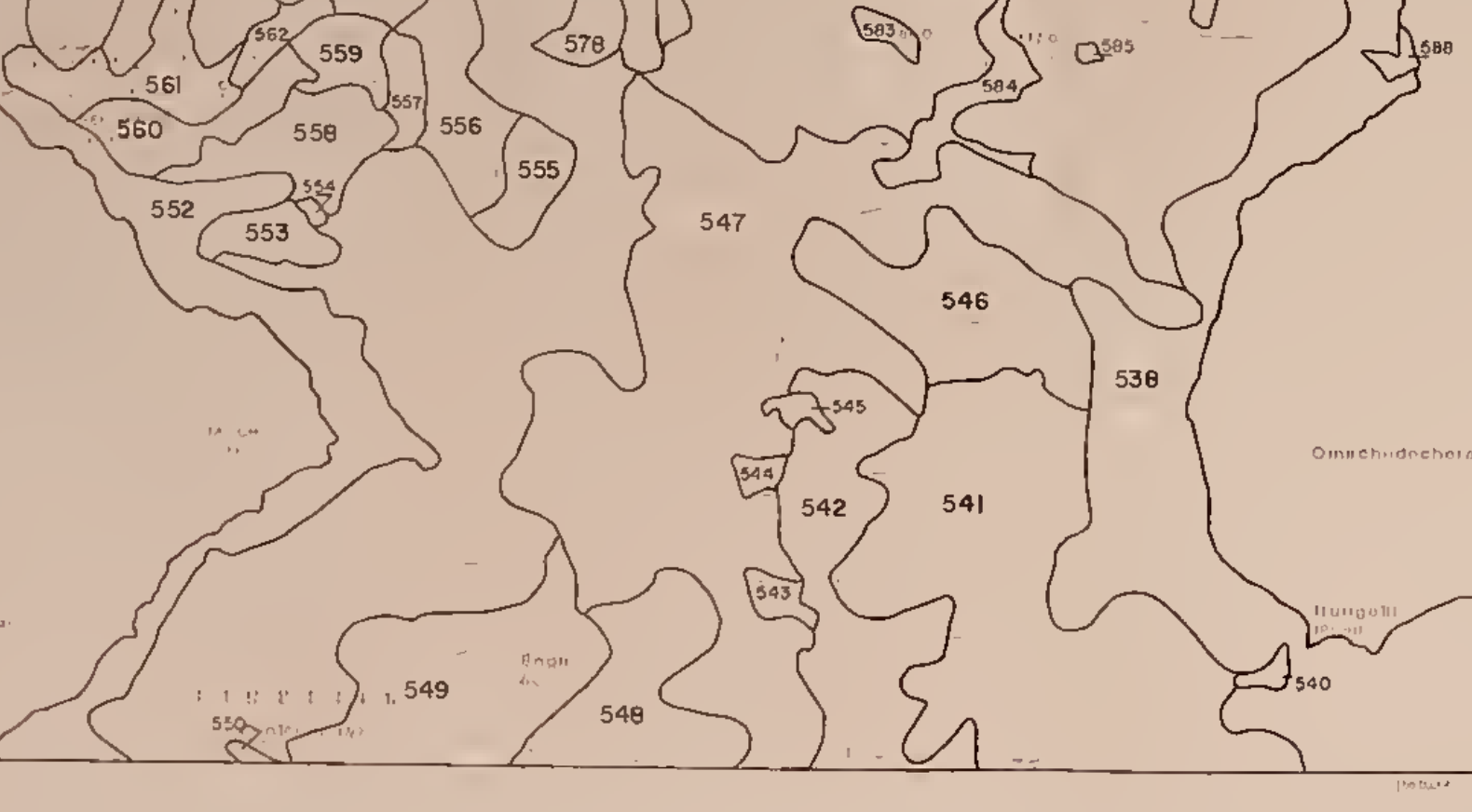
(1) (3)

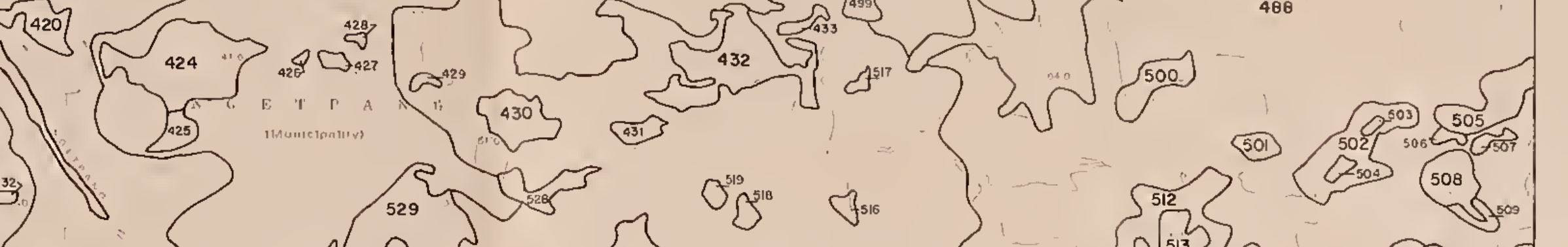
$7 \quad \int 20$ 


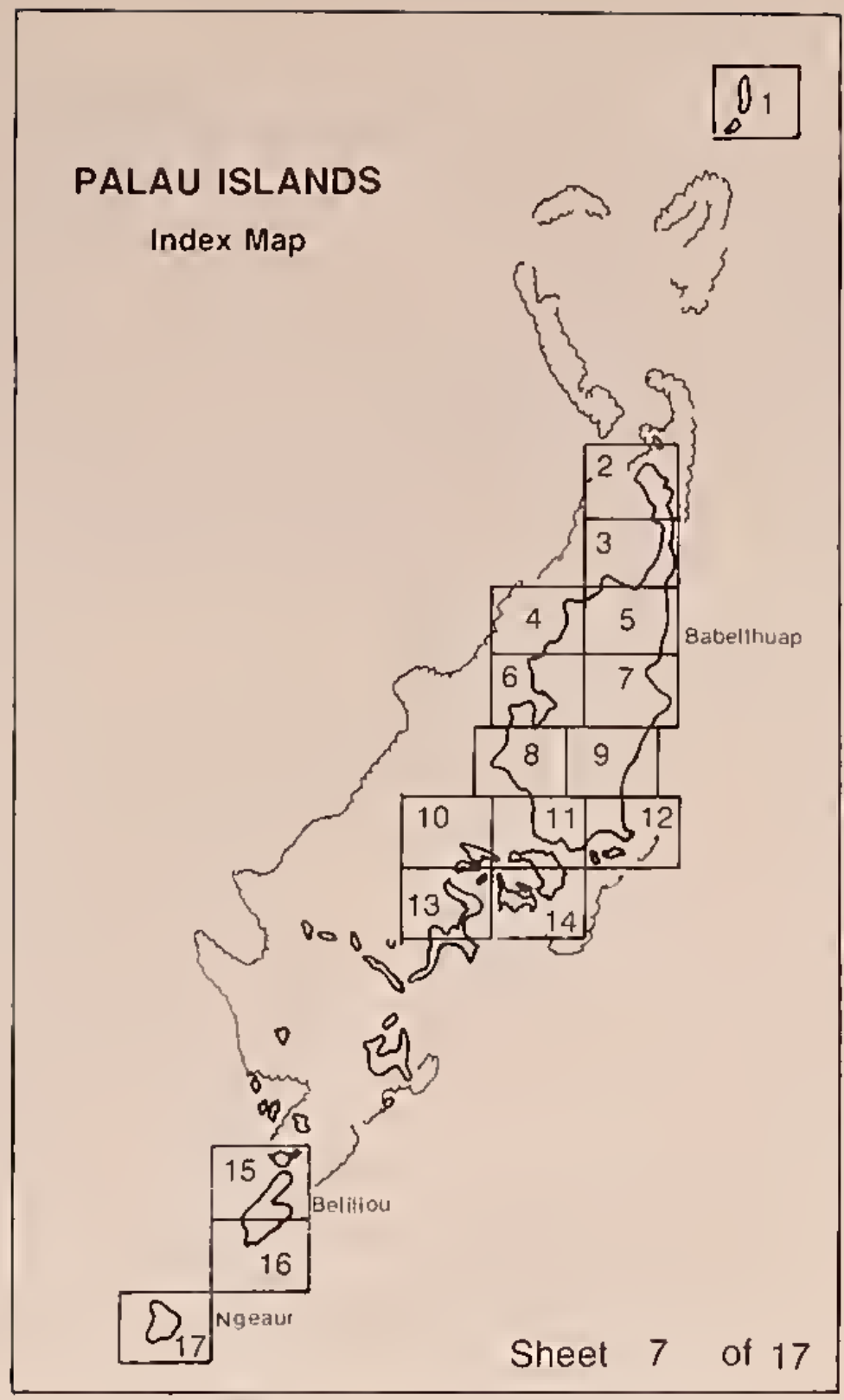

Cole. Thomas G. Fatanruw, Marjorle C. MacLean, Colın D. Whilesell, Cralg D, Ambacher, Alan H. Vegelation survety uf

lhe Republic of Palau Resour Bull. PSW.22 Berkeley, CA

Pacılic Southwesı Foresl and Fange Experrnenl Siation

Forest Service, U S Opparimenl ol Agricullure: 1987 


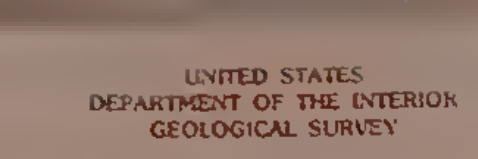

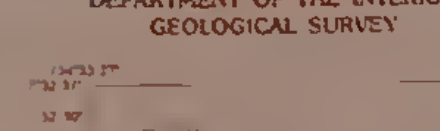

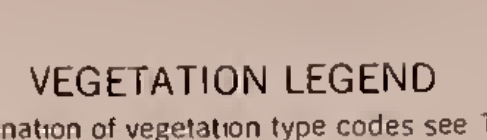
2012)

瓷最

(20)

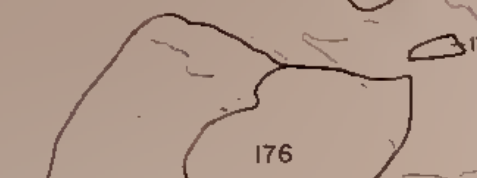

(4) 2

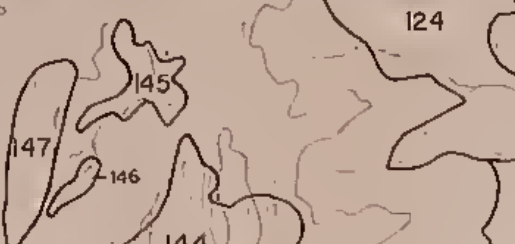

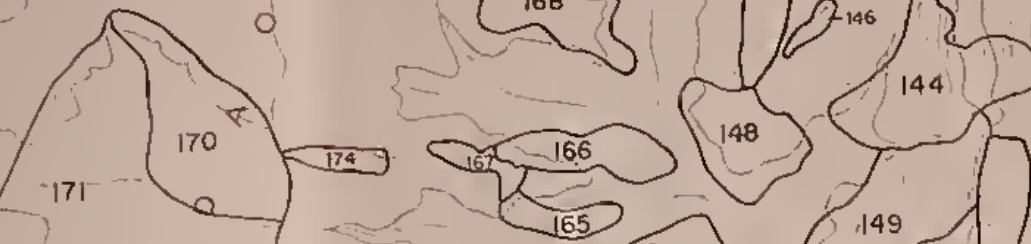

(2)

Sol

3 -

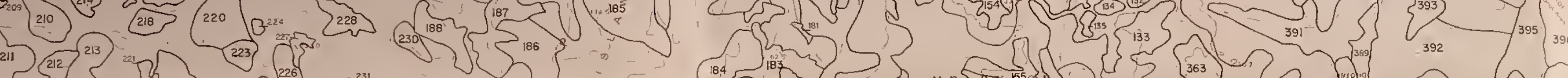
D. 5 (20) (20) $\left\{\begin{array}{l}211 \\ 5\end{array}\right.$

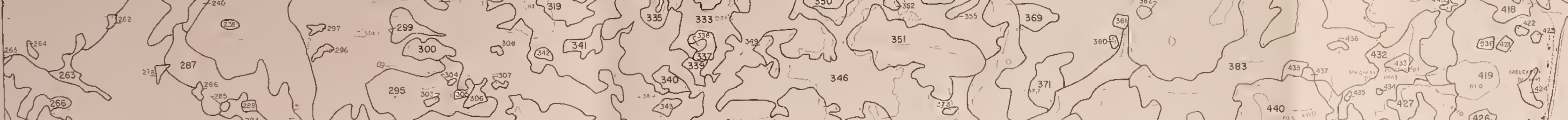
(20) (20) (3)

(4) 


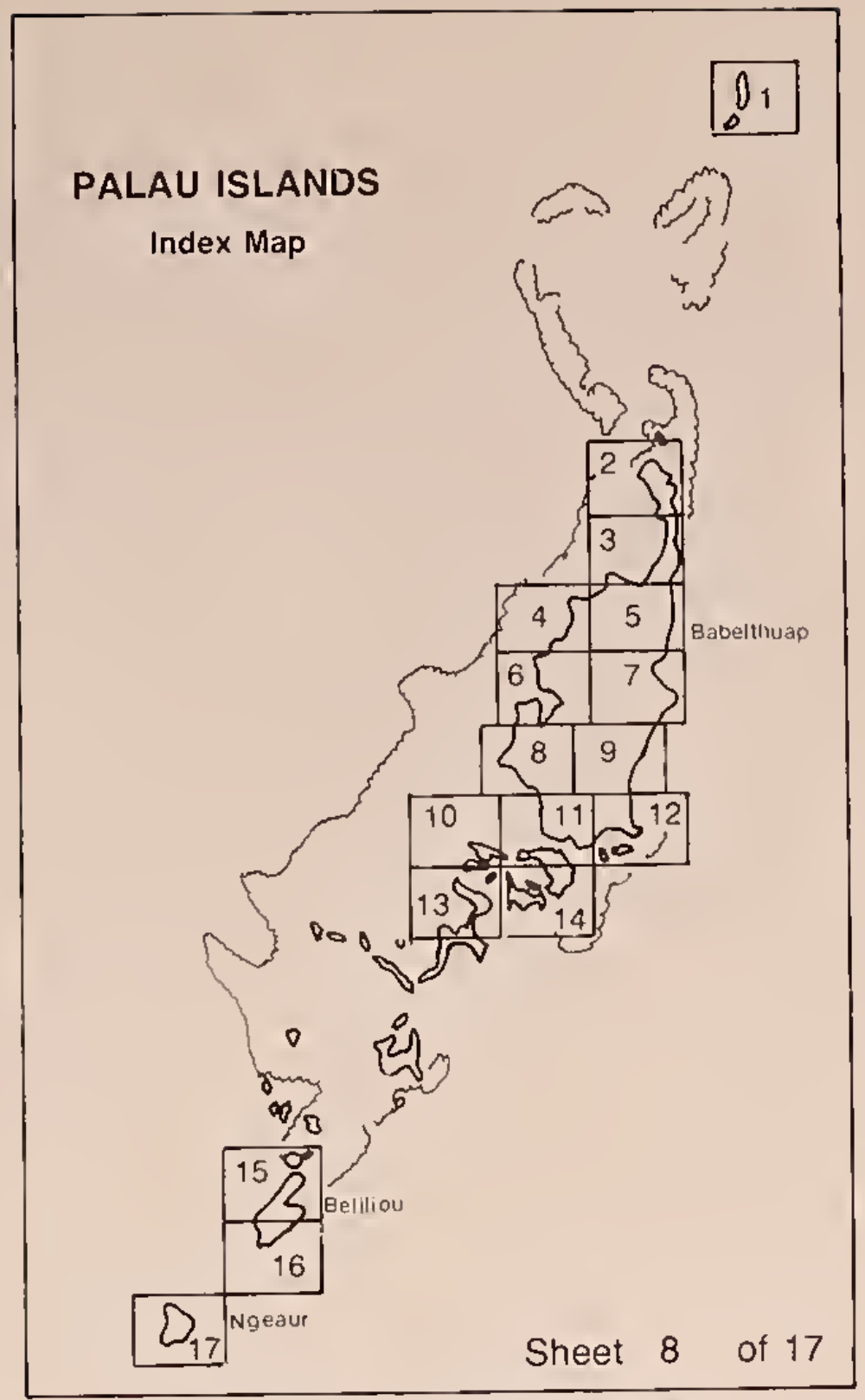

Cule, Thomas G, Falantuw, Małjorte C, MacLean, Colm D Whrtesell, Crang D. Ambaclier, Alan $H$ Vegetatron survey ol Ihe Republic of Palau Resour Bull PSW.22 Berkeley, CA Pacific Soulhwest Foresl and Pange Expesimenl Slalion

Foresl Service, U,S Departmefl of Agriculture; 1987 

2.

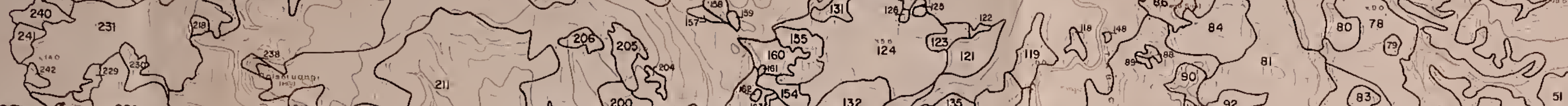

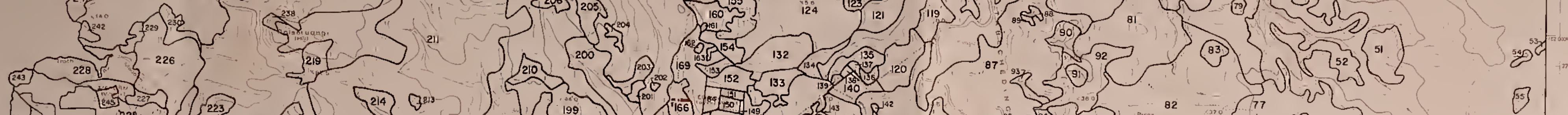

m 3 (

5. Os D. 30 .

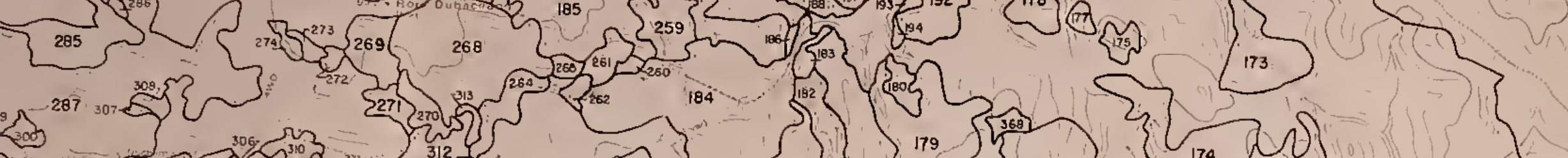
3 ? 3 ?

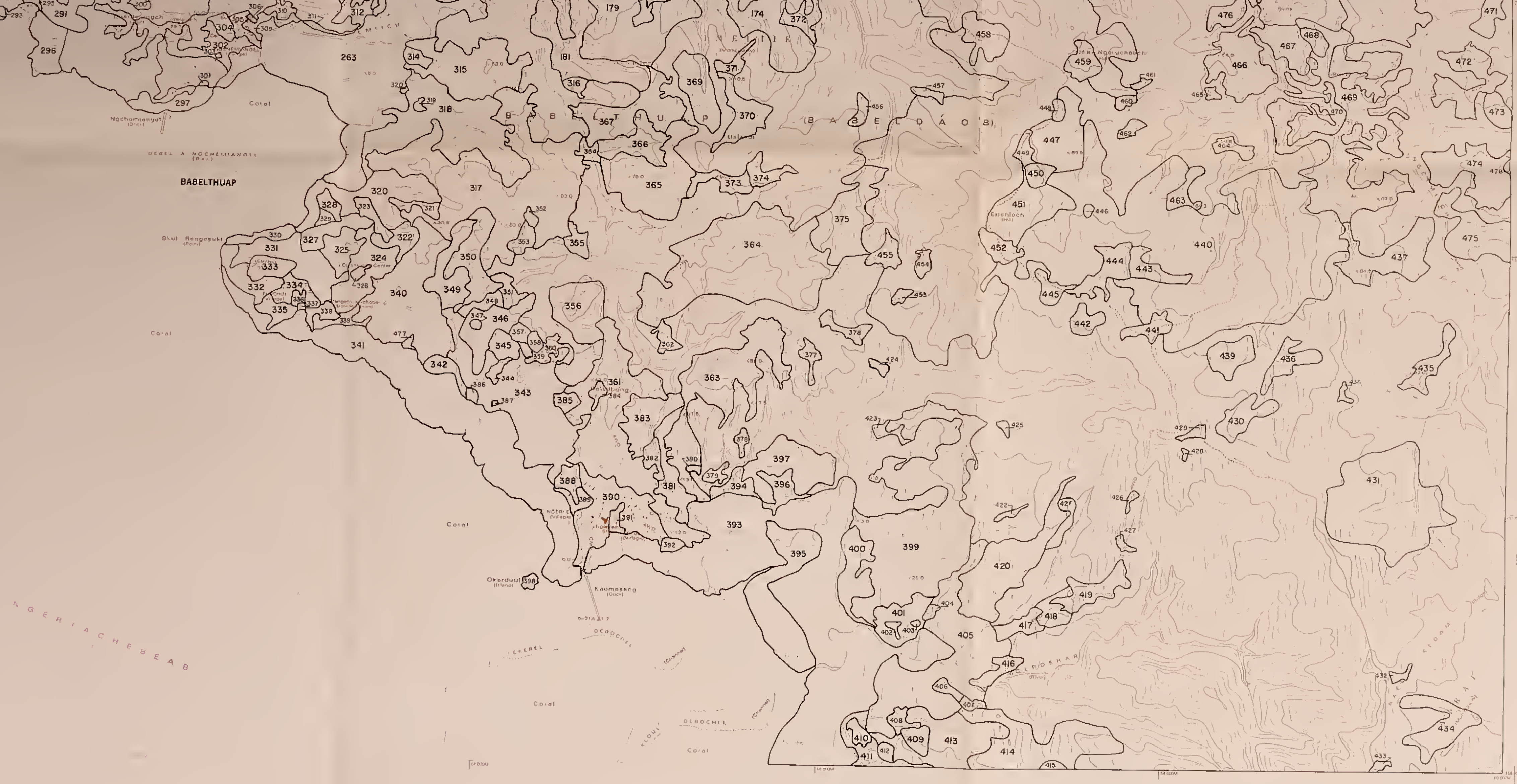

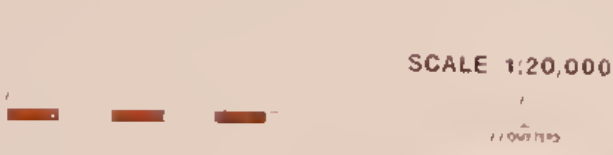




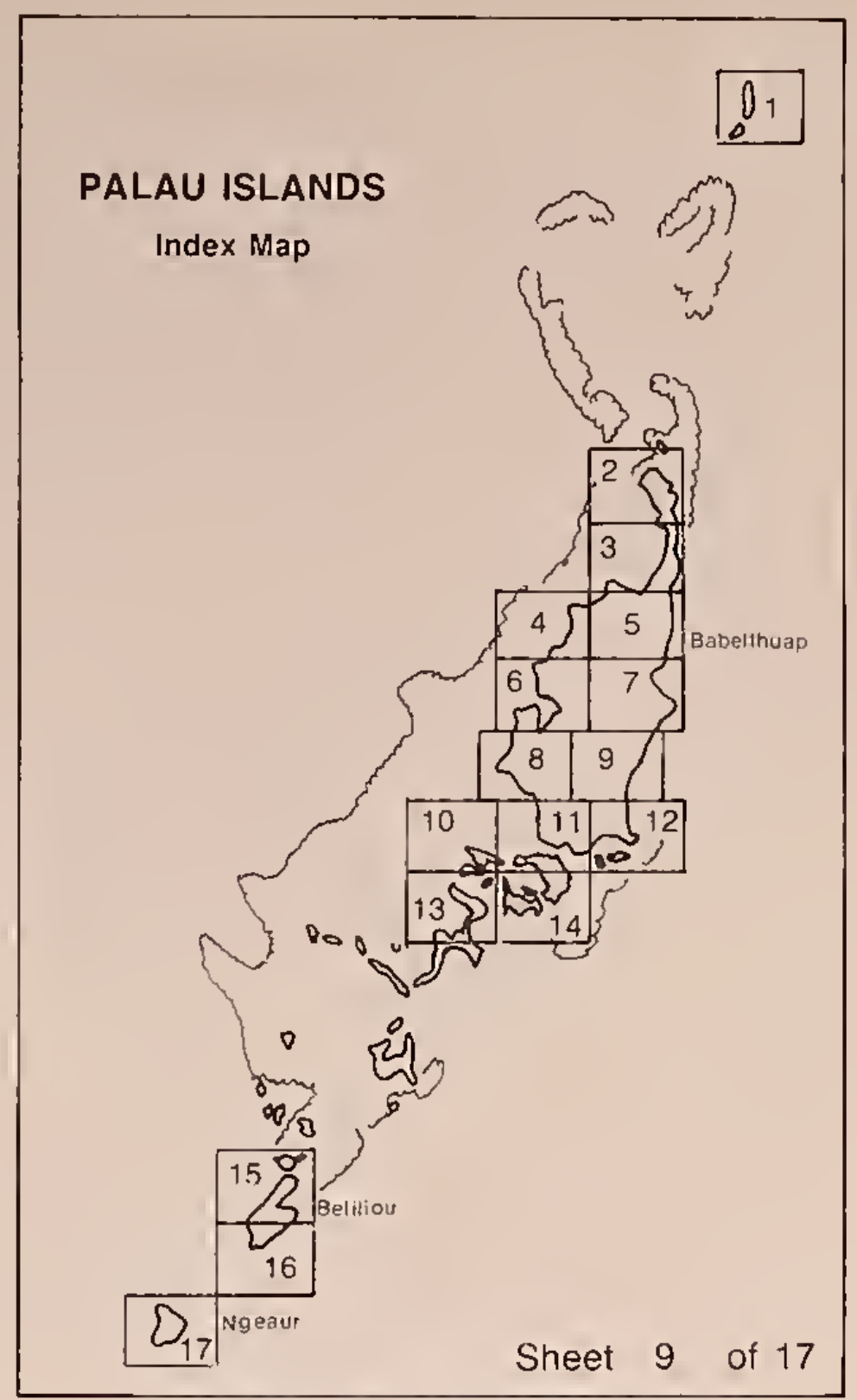

Cote. Thomas $G$, Falanuw, Maujorle C. Mactean, Colin D. Whrteself, Craig O. Ambacher. Alar $\mathrm{H}$ Vegetation survoy of

Ile Republic ol Palau Resour Bull. PSW-22 Berkeley, CA

Pacrlic Southwesl Foresl and Aange Experiment Siation.

Foresl Service. U.S Deparimenl of Agriculture, 1987 


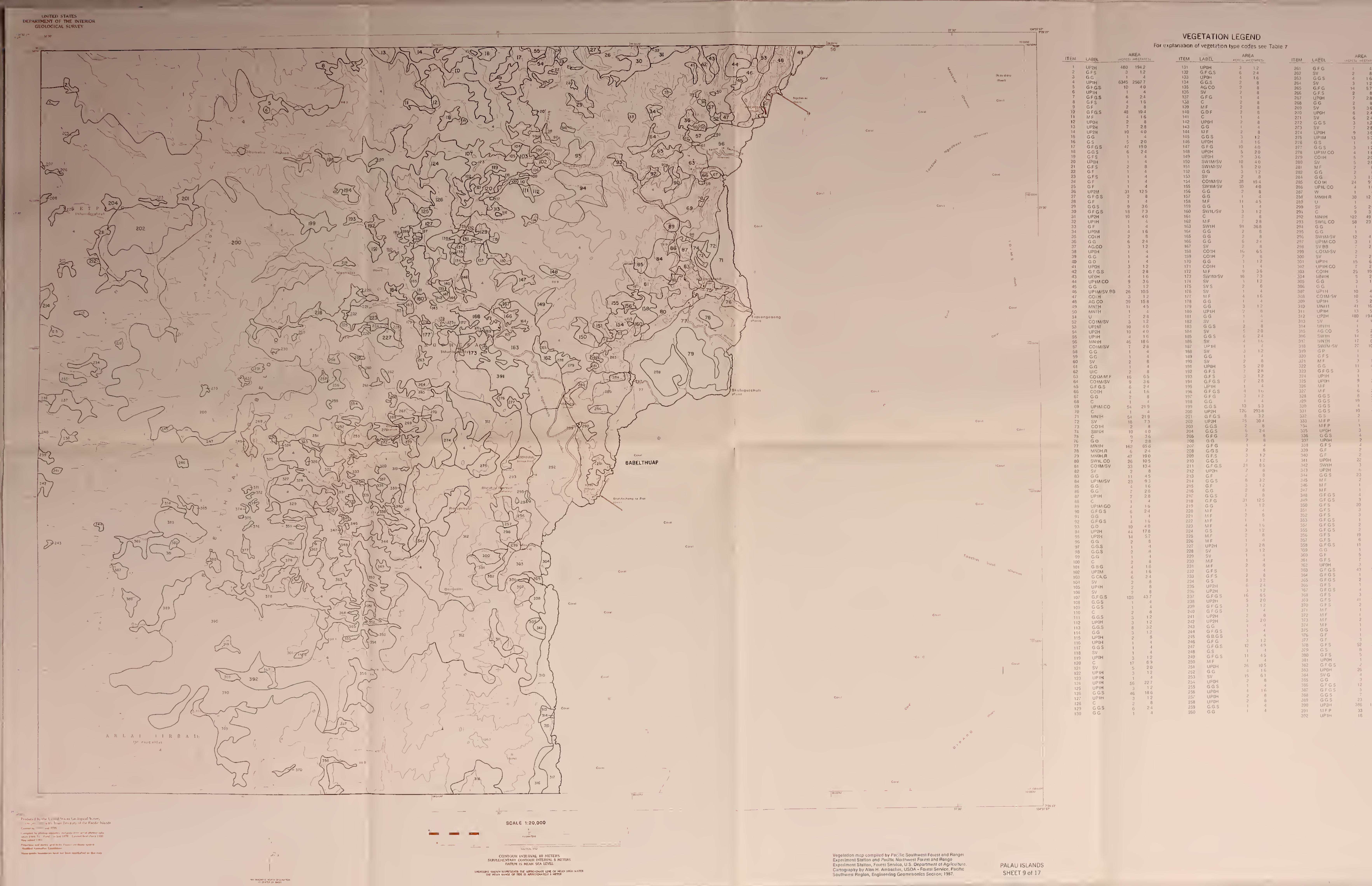




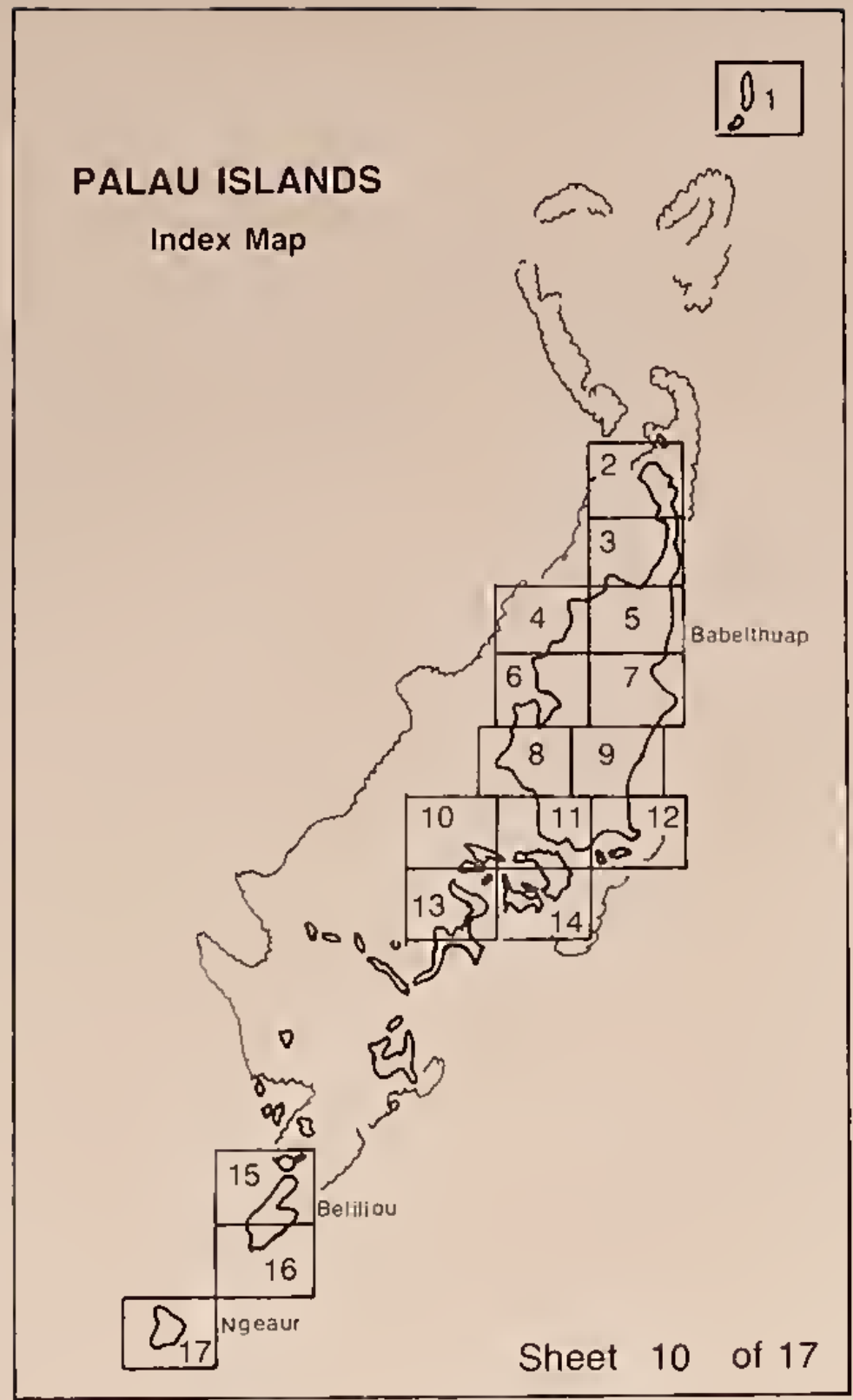

Cole, Thomas G., Faibnruw, Morjorle C. MacLean, Colin D. Whilosell, Craig D.. Ambacher, Alan $\mathrm{H}$ Vegelatian survey a: the Republlc of Palau Resoui. Bull. PSW-22. Beikeloy, CA

Pacitic Soulnwest Forest and Range Expcriment Station.

Folesi Service. U.S. Depariment ol Agricultur 1987. 


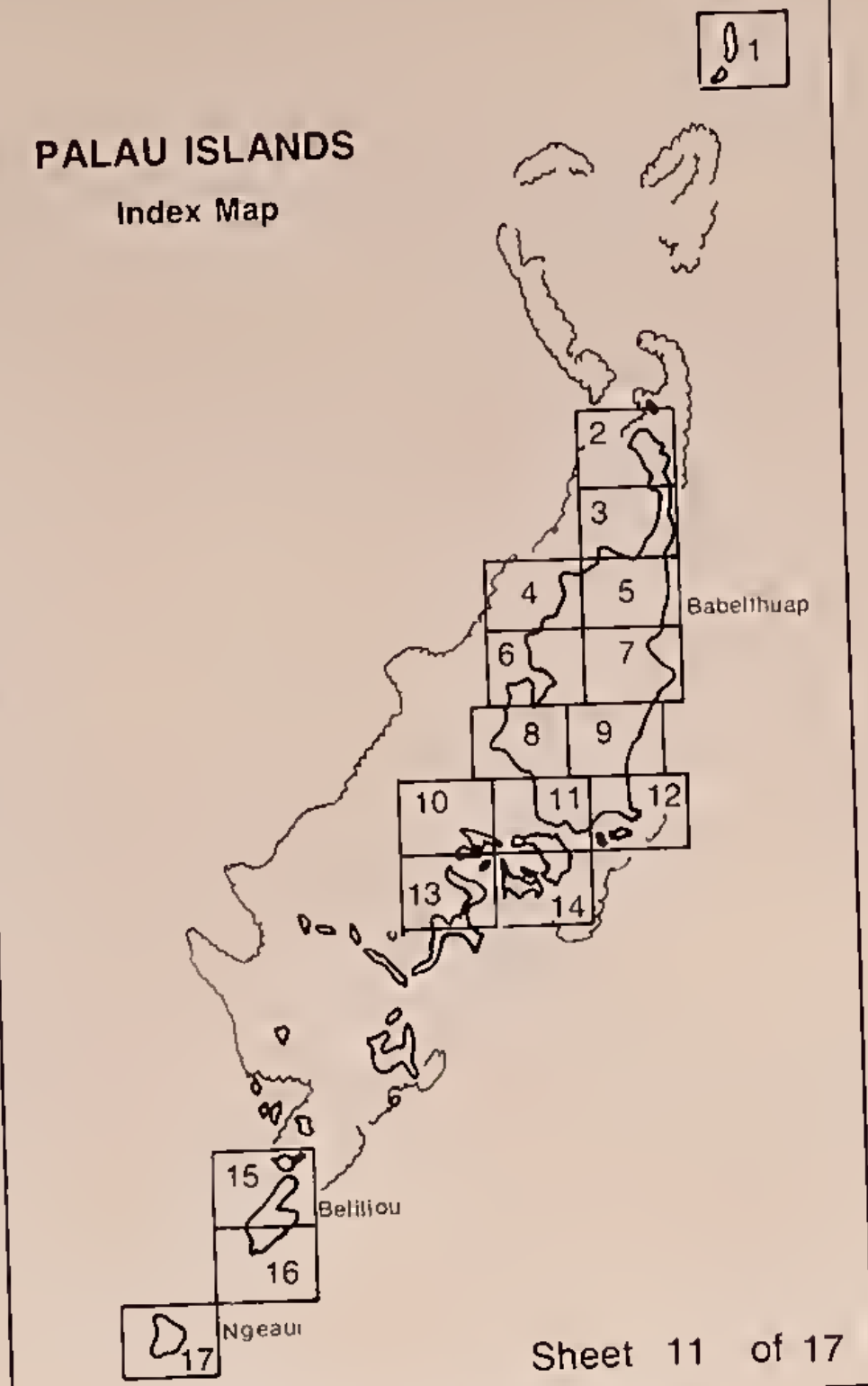

Cole Tnomas G. Falaniuw, Marjorie C, MacLeon, Colin D.. Whileselt, Ciain D. Ambacher, Alan $\mathrm{H}$. Vegetation survey of Whileselt, Claig D., Ambachour, Bult. PSW-22 Berkeley, CA the Republic of Patzu. Resour, Bult. Psweiment Siation. Pacitic Southwost Foiest and Range Expeniment Slation. 


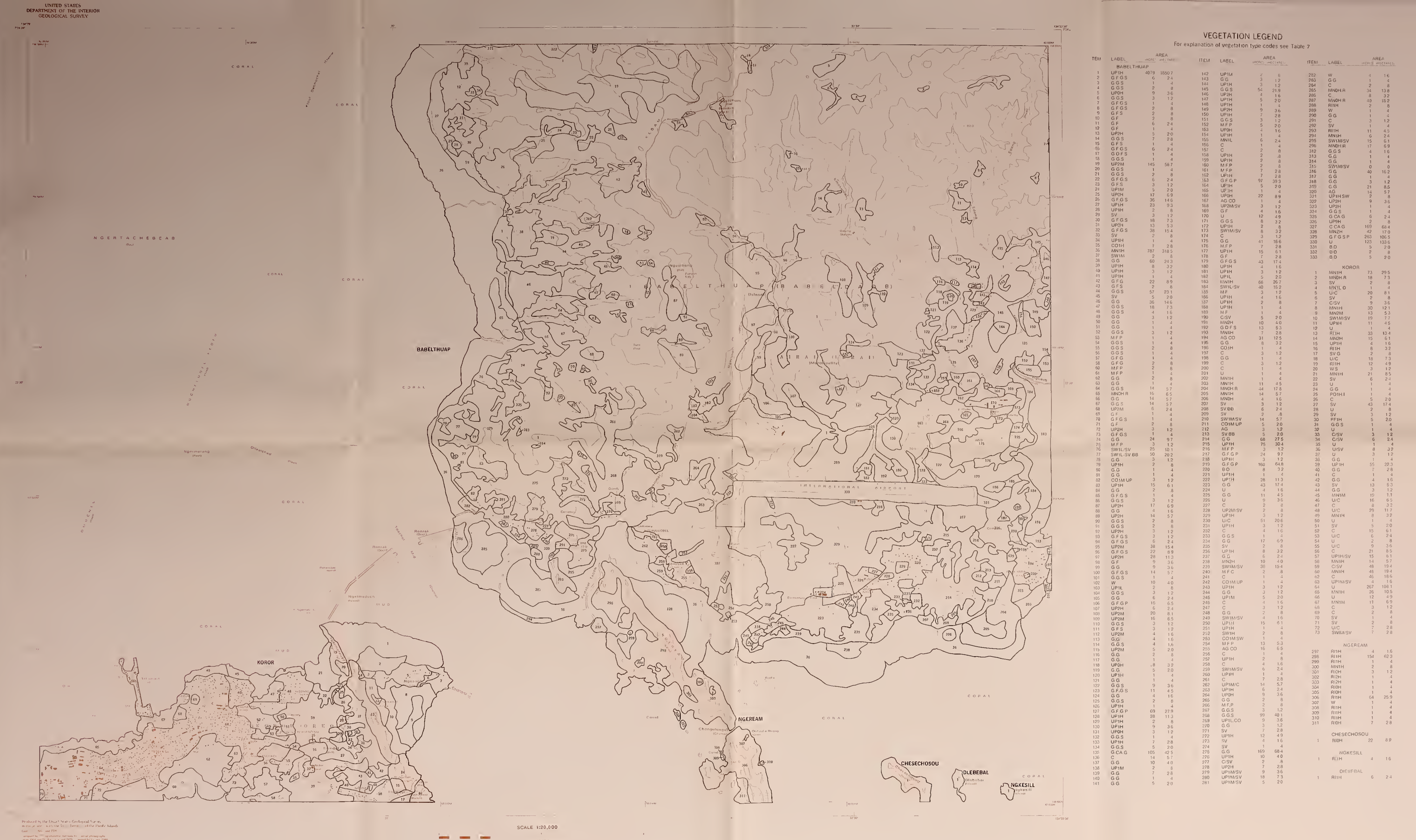




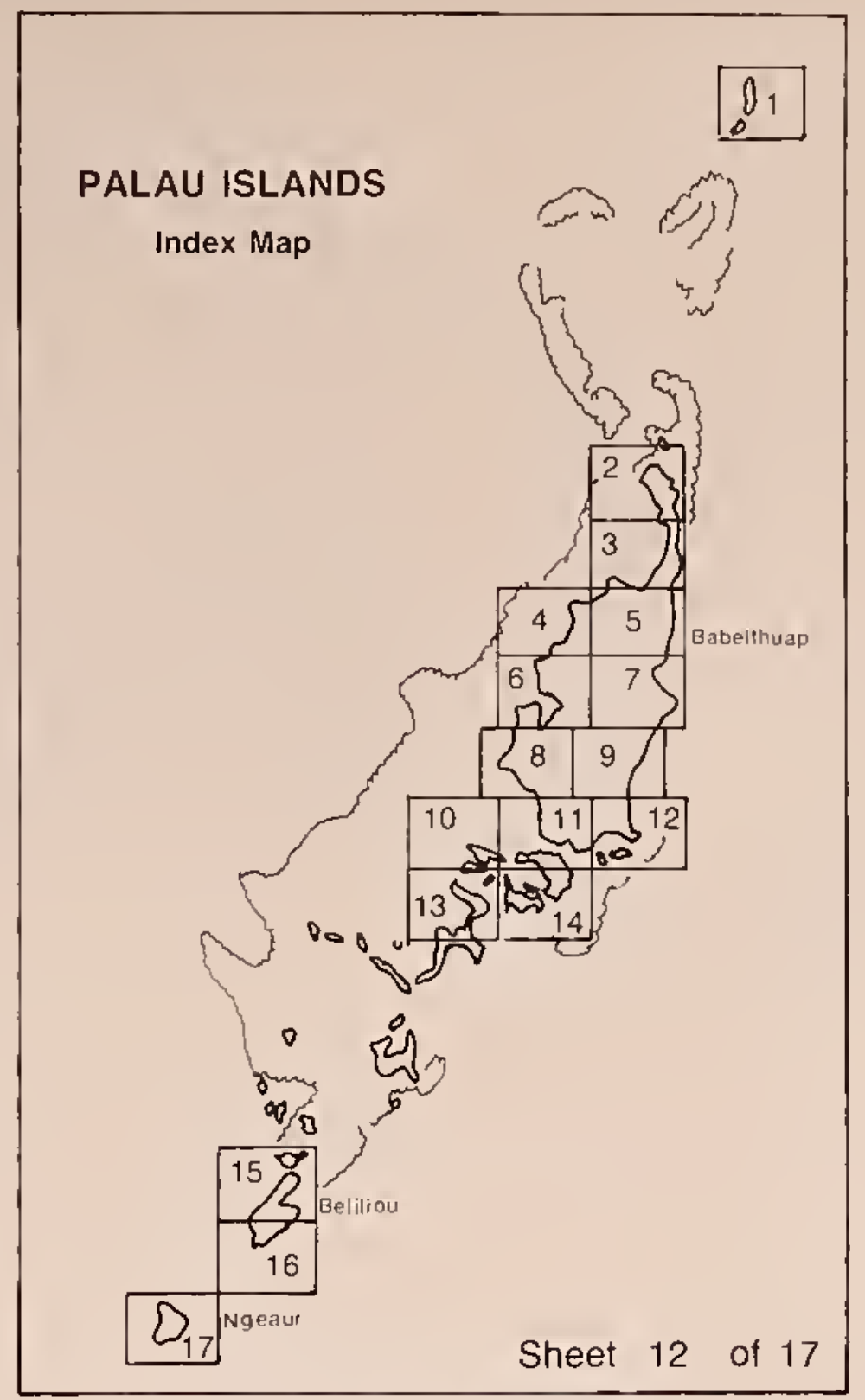

Cole, Thomas $G$, Falanruw, Marjorre C, MacLean, Colln D. Whilesell, Cralg O., Ambacher, Alan $\mathrm{H}$ Vegelatron survey of

the Republic of Patau Resour Bull. PSW.22. Berkeley, CA

Pacilic Southwesl Foresl and Fange Experrment Sialion

Foresl Servlec, U.S Depaflmenl of Agrlcullure; 1987 



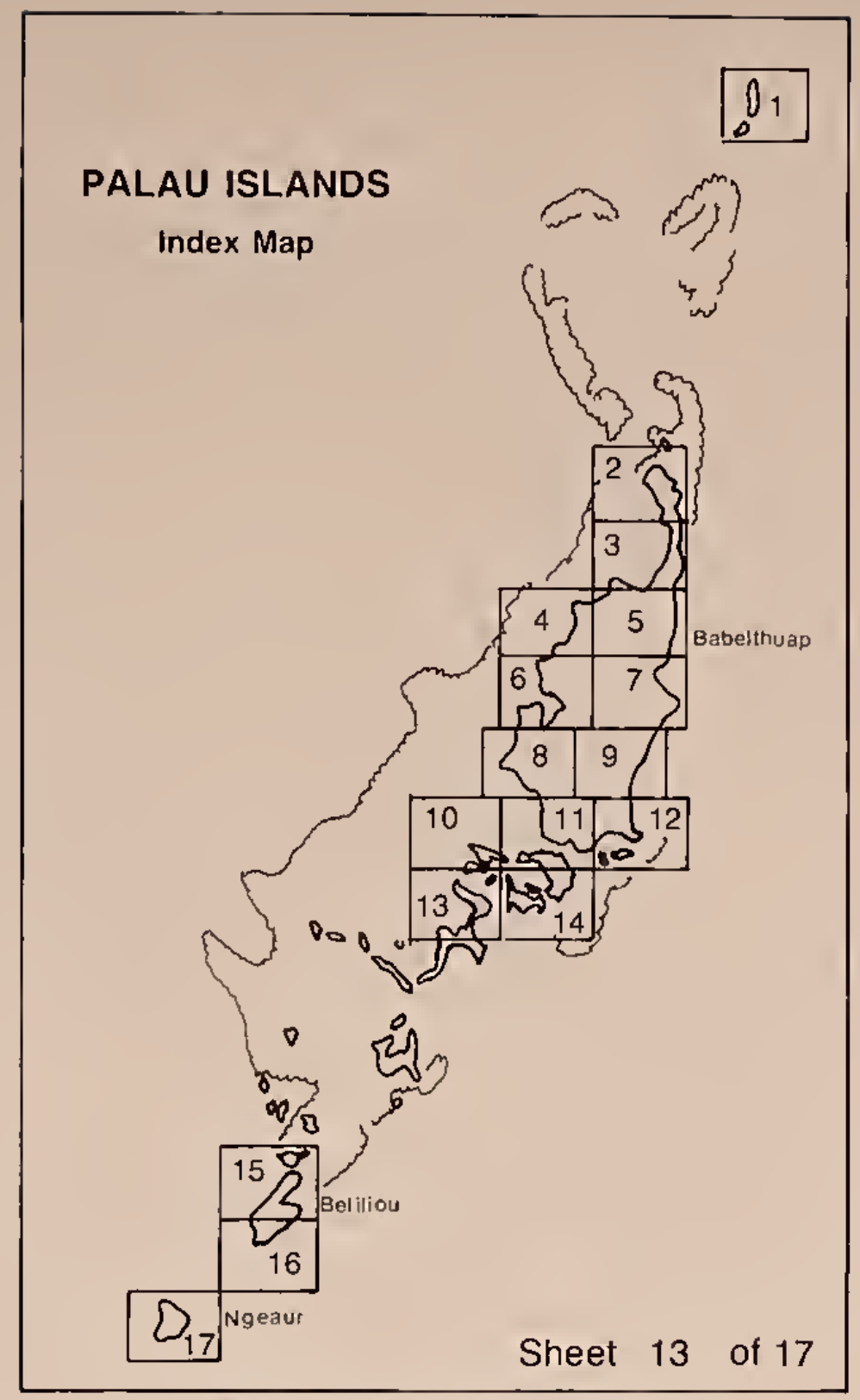

Cole. Thomas G.; Falaniuw, Marjolie C., MacLean, Colın D Whilesell, Craig D., Ambacher, Alan H. Vegetalion survey ol the Republic of Palau Resour, Bull PSW-22 Berketey CA.

Paclfic Southwesl Folesi and Aange Experimenl Slallon.

Foles: Service, U.S Depailment ol Agicullure, 1987 


\section{PALAU ISLANDS}

\section{Index Map}
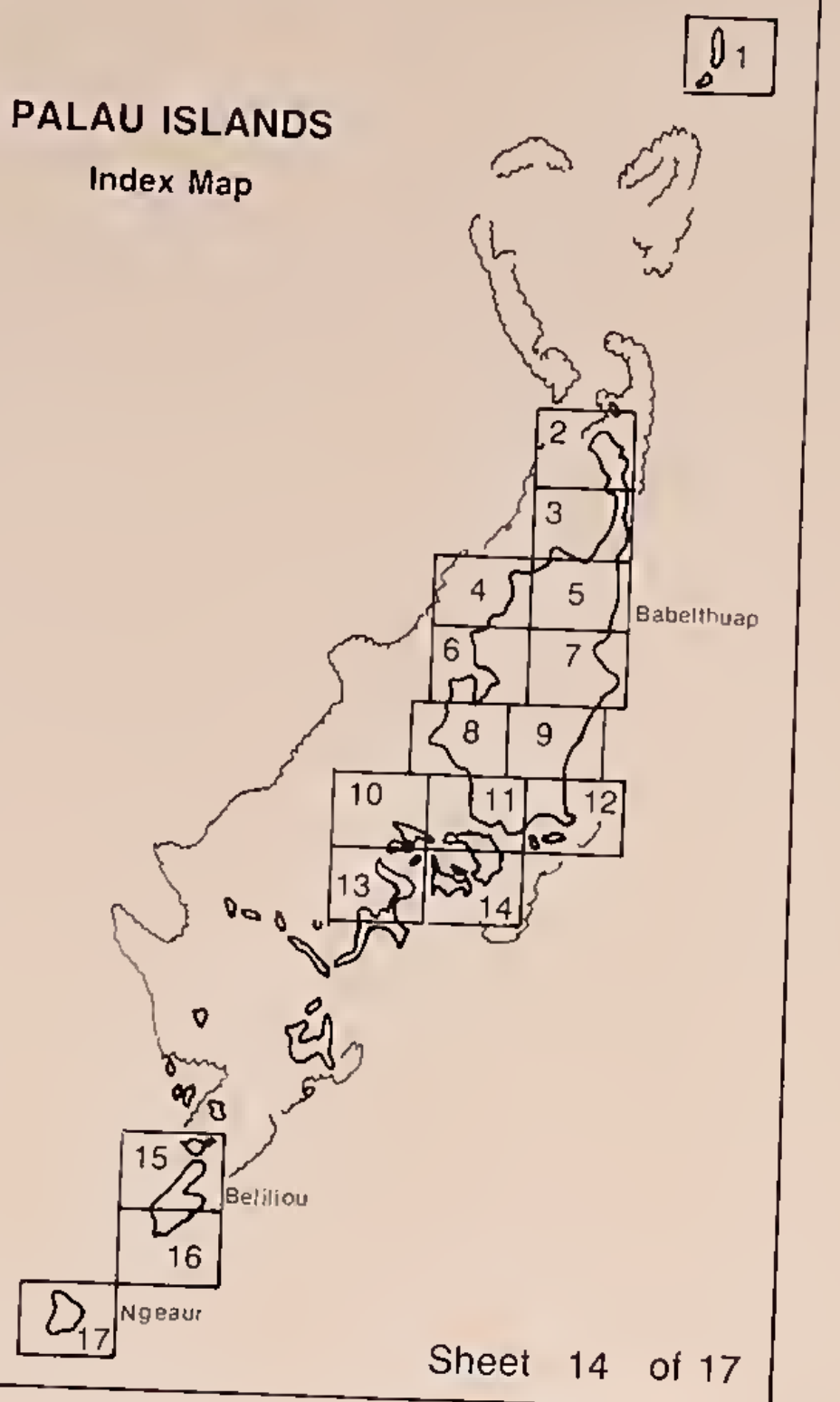

Cole, Thomas G, Falanıww, Maıjorıe C., Maclean, Colin D Whitesell, Cialg D, Ambacher. Alan $H$ Vegelation survey of the Republic of Palau. Resoul Bull PSW-22, Belkeiey, CA

Pachic Southwosl Fares! and Aange Experimenl Station.

ForesI Service, U.S Departmenl of Agriculluie, 1987 


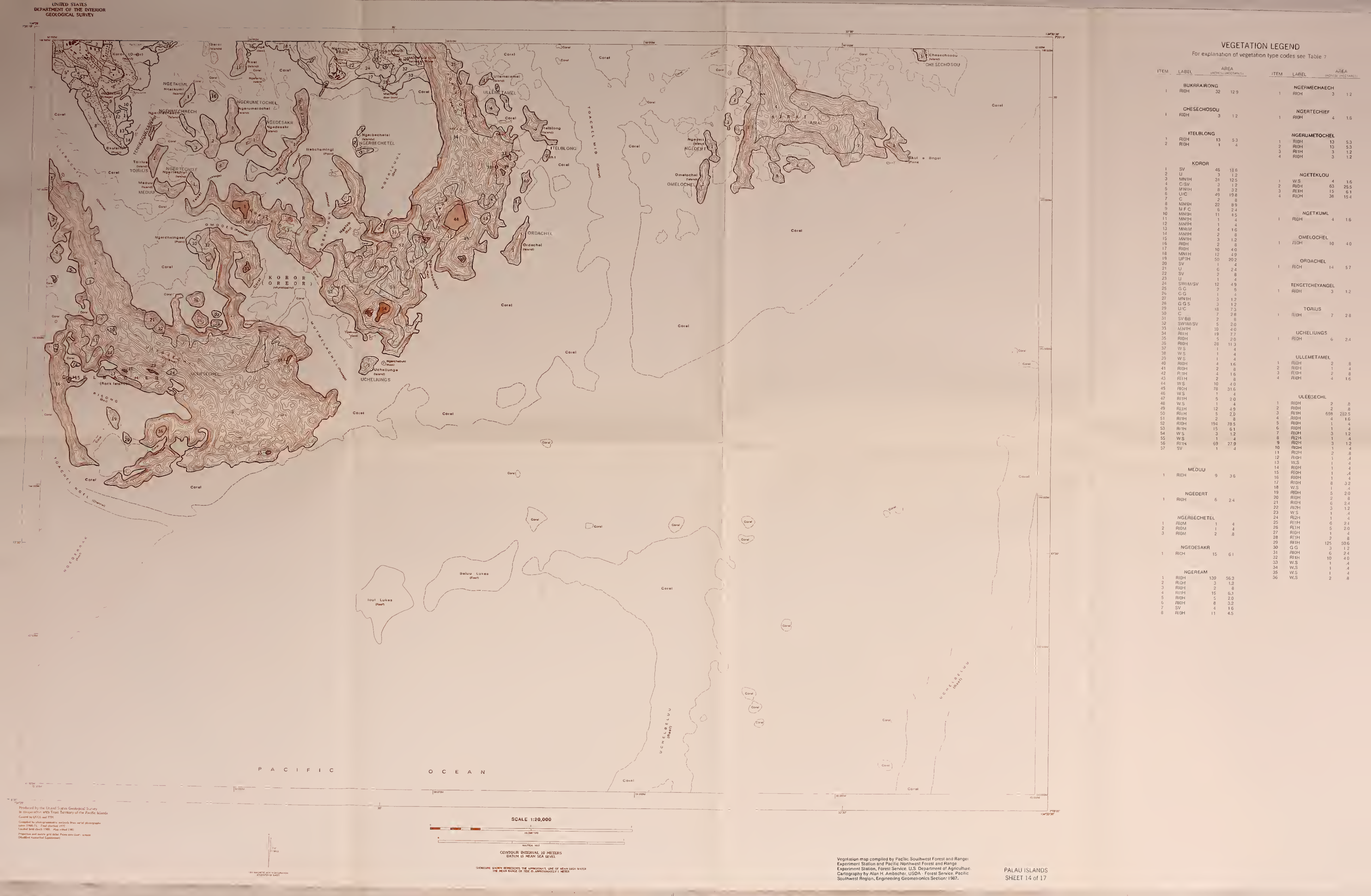




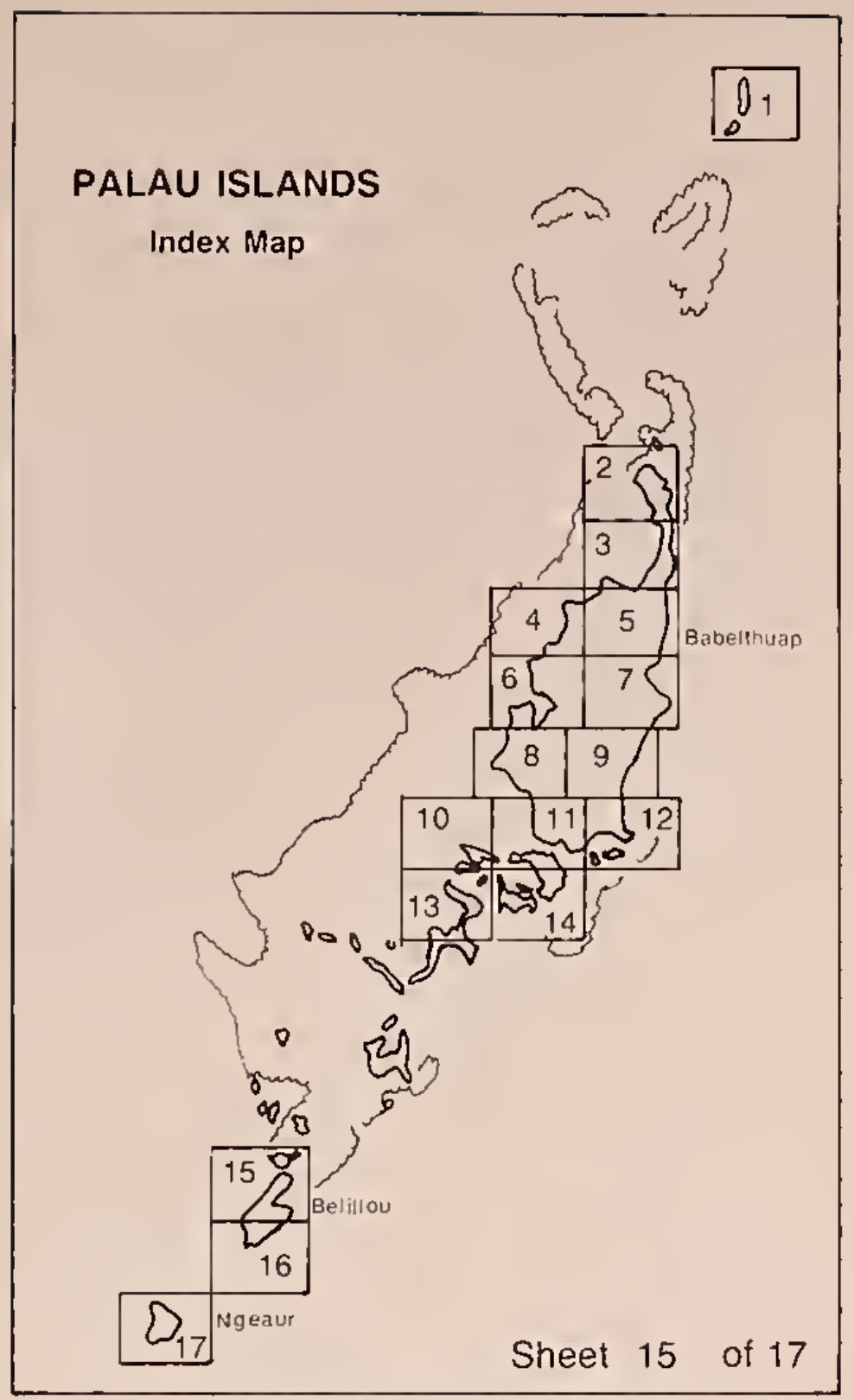

Cole, Thomas G. Falanruw, Maljorig C. MacLean, Colin 0. Whitesell, Clagg $\mathrm{O}$. Ambacher, Alan $\mathrm{H}$. Vegelation survey of the Republtc ol Palau. Resoul. Bull, PSW-22. Berthetey, CA

Pacilic Southwest Folest and Hange Expertment Station.

Folest Service, U.S Depaliment ol Agricultule; 1987 


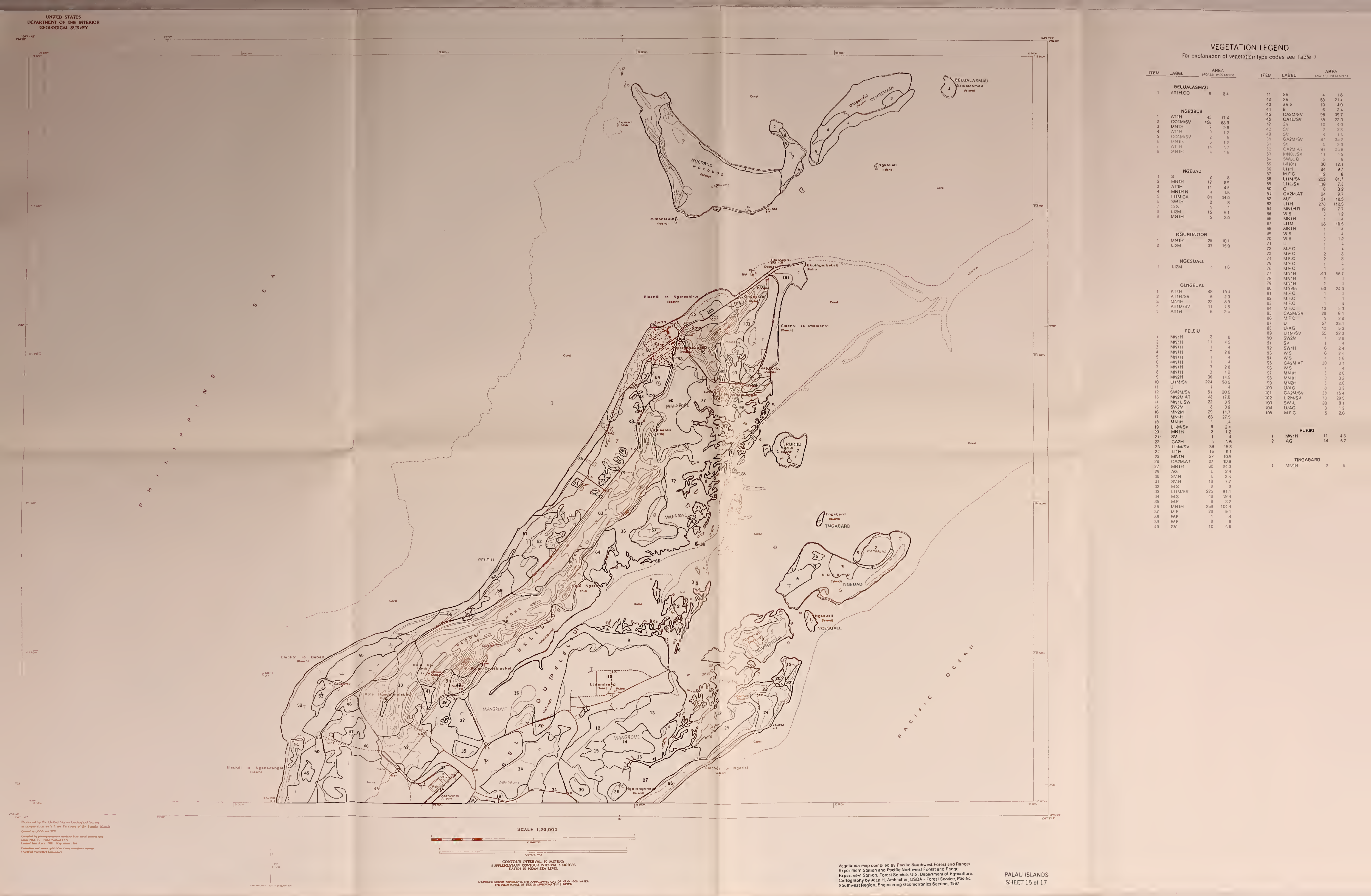




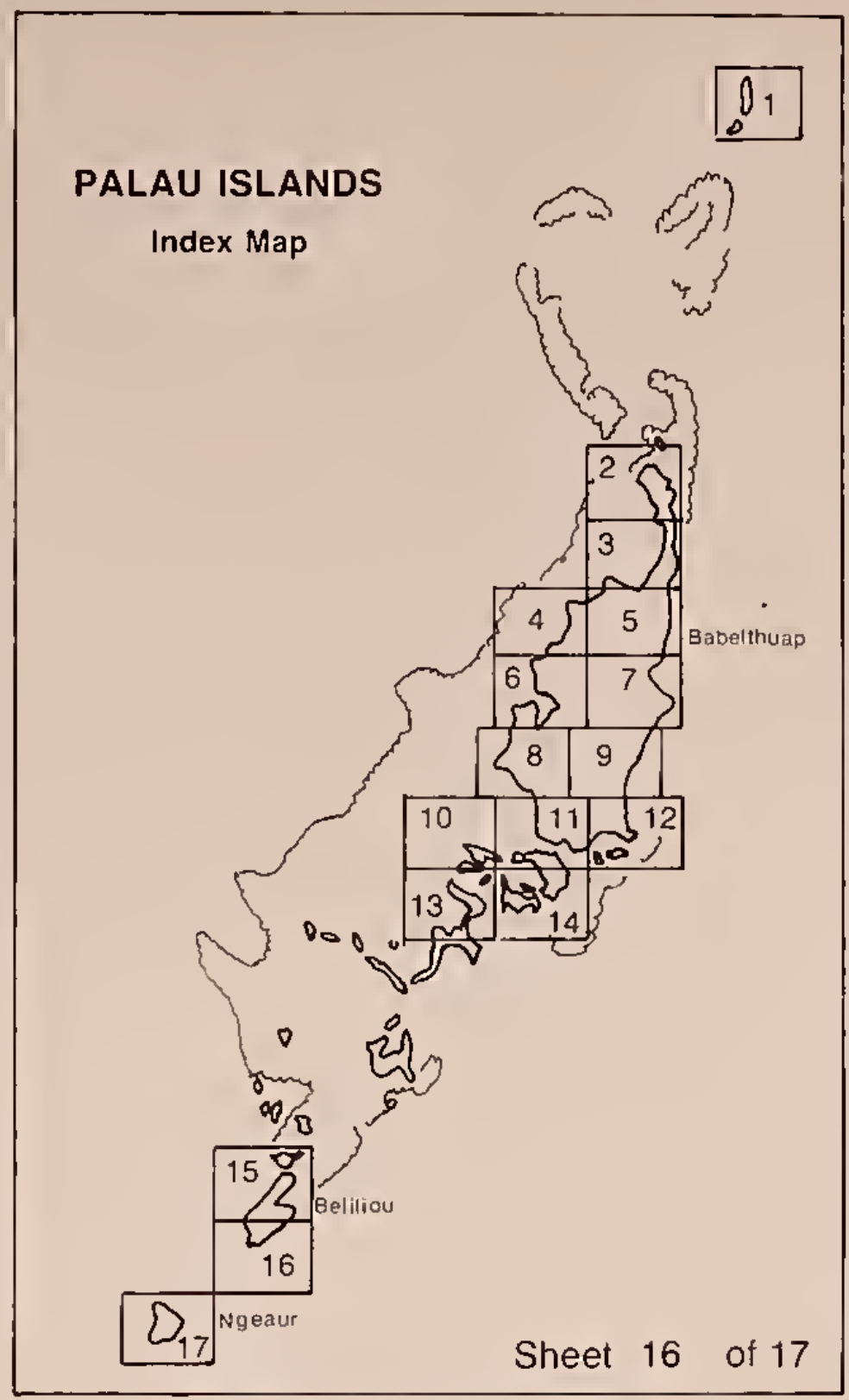

Cole, Thomas G., Falanruw, Murpore C., MacLean, Colin D. Whrlesell, Cratg O. Amtracher, Alan H. Vegetation survey of the Pitpublic ol Palau Rosour, Bulk PSW.22 Berkeley, CA

Paclitc Southwesl Foresl and Aange Experrment Station.

Fores: Service, U.S Depariment ol Agrrculture; 1987. 


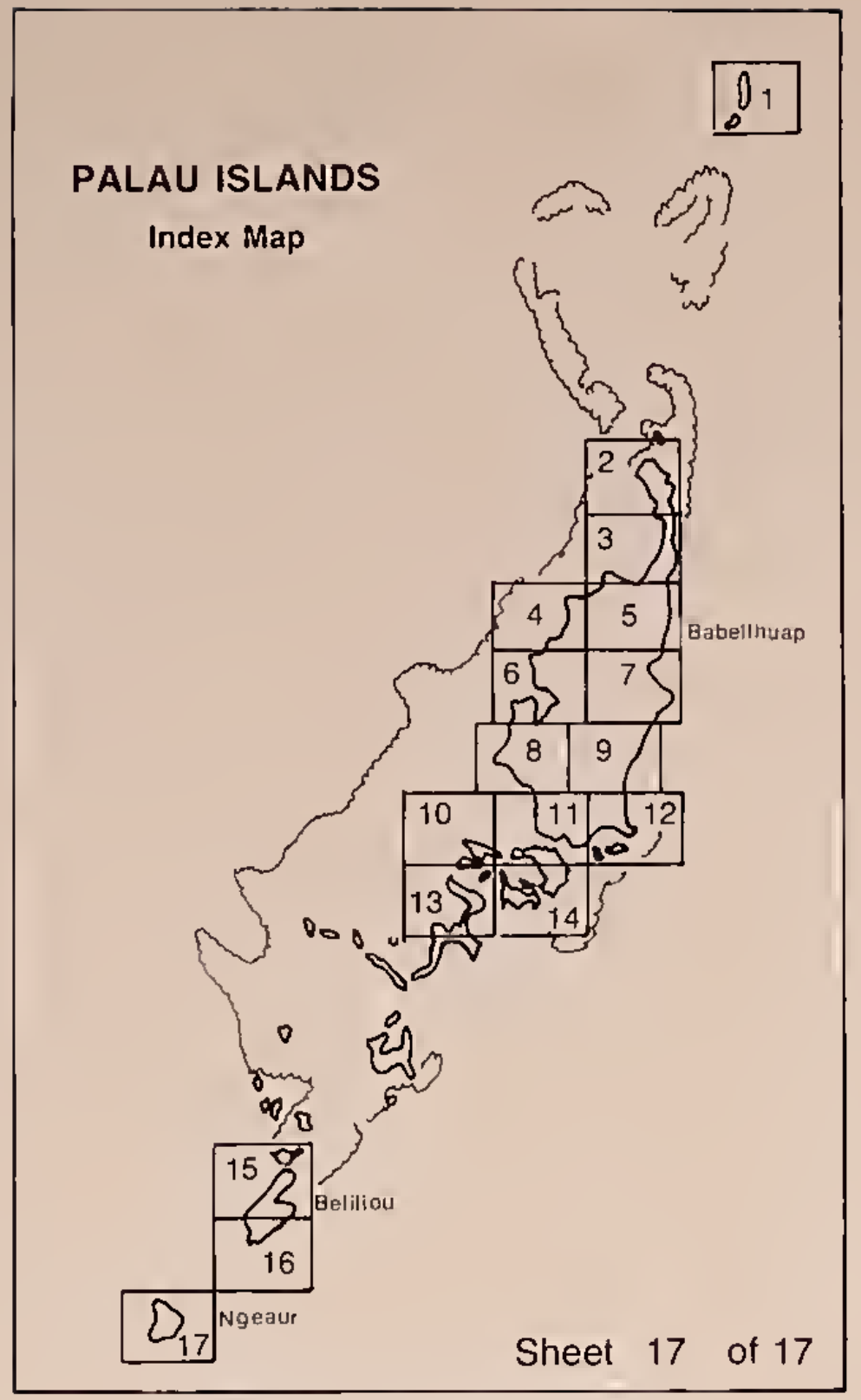

Cole. Thomas G., Falanruw, Marjorie C., MacLean, Colin D, Whilesell, Craig D: Ambacher, Alan Hegelalion survey of the Republic ol Palau Resour Bull PSW-22. Berkeley, CA. Pacilic Soulhwest Foresl and Range Experiment Siation Foresl Service, U.S. Deparimenl of Ageicullure; 1987 


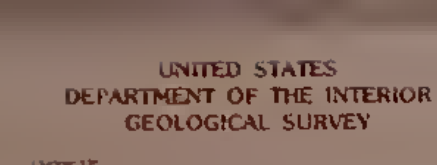
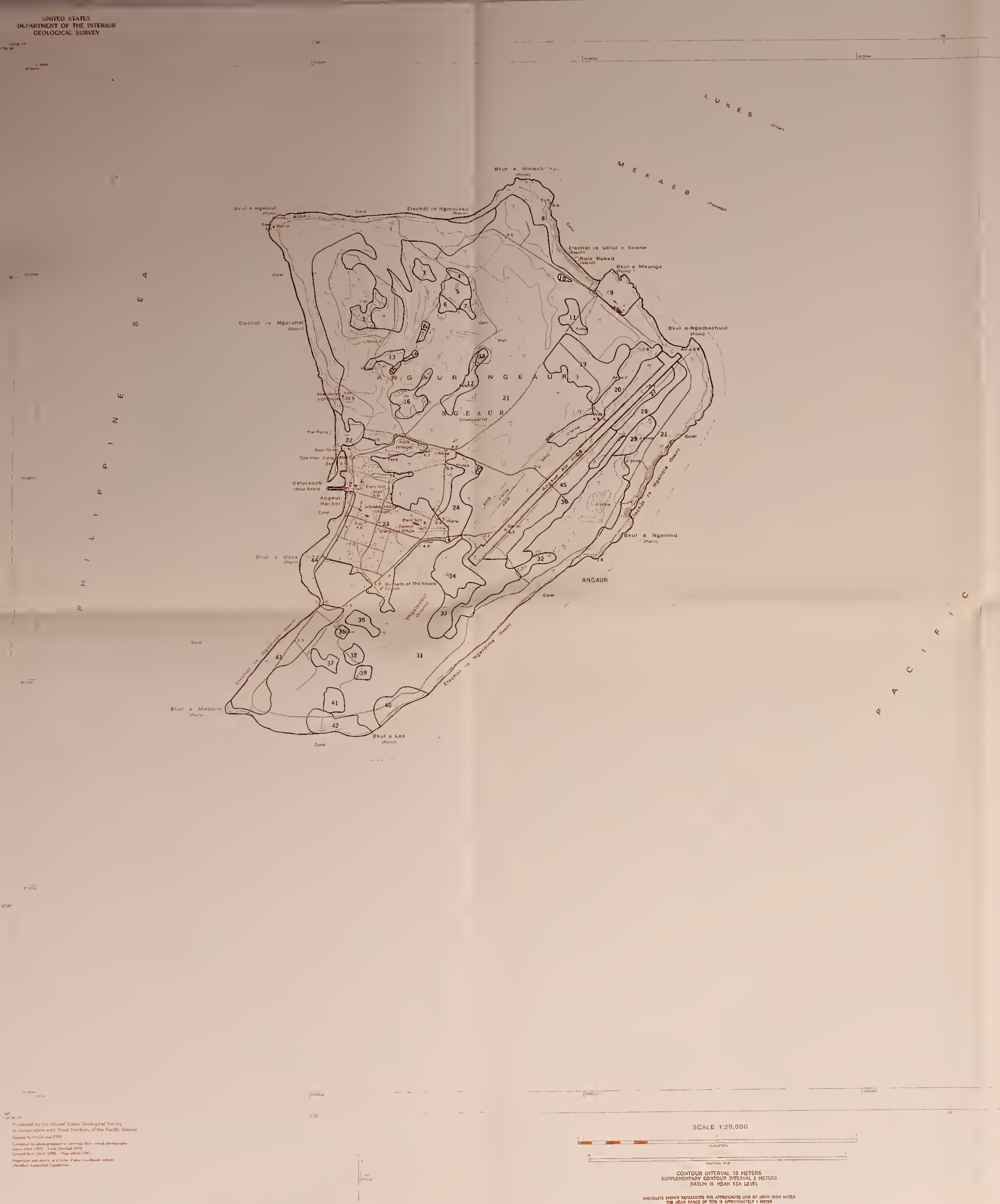
Cole, Thomas G.; Falanruw, Marjorie C.; MacLean, Colin D.; Whitesell, Craig D.; Ambacher, Alan H. Vegetation survey of the Republic of Palau. Resour. Bull. PSW-22. Berkeley, CA: Pacific Southwest Forest and Range Experiment Station, Forest Service, U.S. Department of Agriculture; 1987. 13 p. + 17 maps.

The vegetation of the Republic of Palau, in the Western Caroline Islands, was mapped for land-use planning, forest resource management, and timber volume surveys. The 17 maps show the location and extent of vegetation types identified from 1976 aerial photographs. Forest area is estimated at 31,259 hectares $(77,241$ acres) or 75 percent of the area surveyed. An additional 6,783 hectares (16,761 acres) are grasslands/savannas. At 16 percent of the total area, the grasslands/savannas of Palau have the second greatest land area.

Retrieval Terms: vegetation survey, forest types, vegetation maps, forest resources, Palau, Belau, Caroline Islands, Micronesia 